OPEN ACCESS

Edited by:

Sadiq Umar.

University of Illinois at Chicago,

United States

Reviewed by:

Rehan Khan,

Institute of Nano Science and

Technology (INST), India

Mohammad Ashafaq,

Jazan University, Saudi Arabia

*Correspondence:

Raja Muhammad Rameez Khan rajarameezchm@gmail.com

Mohammad Rashid

rashidchem@gmail.com

Specialty section:

This article was submitted to

Nanoscience,

a section of the journal

Frontiers in Chemistry

Received: 09 February 2020

Accepted: 09 April 2020

Published: 03 June 2020

Citation:

Yaqoob SB, Adnan R, Rameez Khan RM and Rashid M (2020) Gold, Silver, and Palladium Nanoparticles: A

Chemical Tool for Biomedical

Applications. Front. Chem. 8:376.

doi: 10.3389/fchem.2020.00376

\section{Gold, Silver, and Palladium Nanoparticles: A Chemical Tool for Biomedical Applications}

\author{
Sundas Bahar Yaqoob ${ }^{1}$, Rohana Adnan ${ }^{2}$, Raja Muhammad Rameez Khan ${ }^{3 *}$ and \\ Mohammad Rashid ${ }^{2 *}$ \\ ${ }^{1}$ Department of Zoology, Mirpur University of Science and Technology Mirpur, Mirpur, Pakistan, ${ }^{2}$ School of Chemical \\ Sciences, Universiti Sains Malaysia, Penang, Malaysia, ${ }^{3}$ Department of Chemistry, Mirpur University of Science and \\ Technology Mirpur, Mirpur, Pakistan
}

Herein, the role of metal-based nanoparticles (NPs) in biomedical analysis and the treatment of critical deceases been highlighted. In the world of nanotechnology, noble elements such as the gold/silver/palladium (Au/Ag/Pd) NPs are the most promising emerging trend to design bioengineering materials that could to be employed as modern diagnostic tools and devices to combat serious diseases. NPs are considered a powerful and advanced chemical tool to diagnose and to cure critical ailments such as HIV, cancer, and other types of infectious illnesses. The treatment of cancer is the most significant application of nanotechnology which is based on premature tumor detection and analysis of cancer cells through Nano-devices. The fascinating characteristic properties of NPs - such as high surface area, high surface Plasmon resonance, multi-functionalization, highly stable nature, and easy processing-make them more prolific for nanotechnology. In this review article, the multifunctional roles of $\mathrm{Au} / \mathrm{Ag} / \mathrm{Pd} \mathrm{NPs}$ in the field of medical science, the physicochemical toxicity dependent properties, and the interaction mechanism is highlighted. Due to the cytotoxicity of $\mathrm{Ag} / \mathrm{Au} / \mathrm{Pd} \mathrm{NPs}$, the conclusion and future remarks emphasize the need for further research to minimize the toxicity of NPs in the bio-medicinal field.

Keywords: nanoparticles, gold, silver, palladium, toxicity mechanism, physico-chemical toxicity

\section{INTRODUCTION}

The advent ofproduction of large advanced Nano-scaled technology encourages the usage of noble metal-based NPs for diagnosis of diseases, selected drug delivery, biological treatment of cancerous cells, and bio-imaging. The NPs' size, optoelectronic properties, and structural morphology has attracted the attention of researchers toward their potential biomedical applications (Zhang et al., 2019). There has been progress in the synthesis of Nano-sized materials and the surface engineering on these particles through definite ligands that allow the NPs to be modified to achieve the precise shape, biocompatibility, disparity (Rai et al., 2016). This bioengineering modification permitted the development of the drugs that are based on metal architectures framework. However, the silver, palladium, gold, and iron nanostructures are widely studied in modern research. The vastly complex, multi-layered and multifactorial connections of metal-based nanoparticles (NPs) with biotic systems are of great importance. The absence of the stability of toxicological facts prevent the extensive application of these Nano-based pharmaceuticals (Bierkandt et al., 2018; Azharuddin et al., 2019). Moreover, constant efforts have been made to improve their activities and safety profiles for clinical applications. The NPs 
acquire potential characteristics and features e.g., molecular fluorophores which are efficient to make an ideal source for diagnostic-based applications (Agarwal et al., 2019; Khadpekar et al., 2019). The characteristic properties of NPs are: the size must be in the rage of $1-100 \mathrm{~nm}$ and have great surface-volume relation; shape and compositional requirements; qualitative and quantitative target-binding activities; and the greater toughness (Kumar et al., 2011; Sharma et al., 2019; Singh et al., 2019). The size of NPs plays an important role in Nanobiotechnology that makes it more prolific for all of their biological applications. Nano-range proposes several more benefits than other bulk structure materials. Nanoparticles' chemical and physical characteristics can have a substantial effect on general functions like target-binding activities. The physiochemical properties of NPs, increase the tolerance toward biocompatibility. In the biological sciences, NPs have an extensive history of bioconjugation with protein, peptides and DNA, cellular delivery systems and labeling agents (Leso and Iavicoli, 2018). The light-scattering property of the material depends on the shape, size, and surface of the molecule, which makes the material prolific for multiplexed agent exposure for biotic moieties. Currently, several methods and technologies for engineeredbased materials like superficial modification, size control, and designing have touched upon the advance production of large Nano-range NPs for both micro and macro size molecules (Singh et al., 2018; Handoko et al., 2019; Yaqoob et al., 2020c). According to the literature, engineered NPs with abilities to modify physical and chemical characteristics, offer to make it more progressive and extremely vigorous in terms of binding affinities for several types of biomolecules and the treatment of cancerous cells and viruses like HIV. In brief, the most significant breakthroughs in today's modern chemical sciences are attributed to nanotechnology (Aderibigbe, 2017). Mostly, the noble metals are considered useful due to notable catalytic, electronic, magnetic, optical, and mechanical properties. The characteristics and possible applications of nano range noble metals have developed a significant and theoretical approach in different applications (Sakthivel et al., 2019). In this regard, the most commonly employed noble metals are $\mathrm{Au}, \mathrm{Ag}$, and Pd that are very rare and valuable. These carried a great revolution in the biological and medicinal fields in the modern era as compared to other materials (Yaqoob et al., 2020a). The unusual physical property of the gold metal such as high resistance to corrosion makes it bio-compatible for medical applications; it is very suitable for dealing with a diversity of diseases like skin ulcers, syphilis, cancer, smallpox, AIDS and measles (Daniel and Astruc, 2004; Chitra, 2018). Currently, gold nanoparticles (AuNPs) received much attention for the critical disease diagnosis and the treatment of several diseases e.g., cancer, HIV, and rheumatoid arthritis, whereas substantial exploration is currently promising for possible applications as anticancer, antibacterial and biodiagnostic material (Yaqoob et al., 2019). AuNPs contain substantial positions in the medical treatment field due to their relative chemical stability that makes the preparation and fabrication methods modest, straightforward, and less dangerous. Additionally, the developments led the scientists to produce Nanostructures that can be conjugated to numerous types of biotic molecules with antibodies (Shenoy et al., 2005; Jabr-Milane et al., 2008; Ho et al., 2010). It can influence the targeted cells stating through receptors. Colloidal-based Au has been carrying a significant role in the medical field while the precise mechanism to exploit it is not completely understood. Nowadays, the AuNP's applications are growing gradually in pharmacological sciences for human safety. It can be employed to comprehend further about diseases such as HIV and cancer by offering substantial targets through Nano-vesicles (Potineni et al., 2003). Silver (Ag) has been used such as an anti-microbial, anti-viral e.g., Phoenicians employed silver vessels to preserve wine and water throughout their far-reaching voyages. In the earlier time, ancient Egyptians thought that the Ag metal is valuable for healing disease (Likus et al., 2013; Yaqoob et al., 2020b). Therefore, AgNP-based chemicals are utilized for the elimination of wound infection before antibiotics. Nowadays, Ag-based cream named Ag-sulfadiazine is commonly used for antibacterial treatment to cure serious wounds (Aziz et al., 2019). However, insufficient local retention and cytotoxic influence limited the experimental utilization of Ag material. Further, the significant magnetic, transparent and electronic properties of AgNPs can be applied to control the microbial activities (Murphy et al., 2015). Another noble metal is palladium $(\mathrm{Pd})$ that has extraordinary catalytic, and electronic features (Chaloupka et al., 2010; Pattadar et al., 2019). Palladium (Pd)NPs structures have been extensively used in applications such as the electrical equipment composition, as a sensor for exposure to several bio-analytes. In biomedicine, $\mathrm{Pd}$ is very frequently used in dentistry appliances and especially its needles are mostly applied in the health center for prostate cancer therapy and choroidal melanoma therapies. So, despite their notable properties, PdNPs have not been used, until lately, in the Nano-biomedicine applications and the PdNPs offer the prospect for the presence of further active catalyst resources due to presence of larger surface-area-to-volume ratio and its greater surface energy values make it more inexhaustible in the remedial field (Bakuru et al., 2018; Leso and Iavicoli, 2018). In this article, the focus is on the application of noble NP metals, especially, $\mathrm{Au}, \mathrm{Ag}$, and $\mathrm{Pd}$ in the analysis and bioremediation of diseases and the level of their toxicity. The toxicity of the NPs is a very important aspect in the medical applications, herein, we have critically analyzed the physical and chemical properties associated with their toxic effect. Finally, a future perspective of $\mathrm{Au}, \mathrm{Ag}$ and $\mathrm{Pd}$ and the mechanism of toxicity are summarized which might be useful for future research, since these three noble metals have great potential in upcoming biomedical research.

\section{Au/Ag/PdNPs-A BIOMEDICAL PERSPECTIVE}

Disease treatment is hindered through drug resistance, demonstrating an urgent need to introduce novel therapeutics agents. The scientific community declared the metallic-based $\mathrm{Au} / \mathrm{Ag} / \mathrm{PdNPs}$ have been developed for several diseases to remediate effectively. $\mathrm{Au} / \mathrm{Ag} / \mathrm{PdNPs}$ are categorized by their nano range of $10-100 \mathrm{~nm}$. They are considered useful due to the unique interaction of molecules within or outside the 
cell surface. The high surface area of these particles indicates better cell permeability which also refers to the meaningful outcomes. However, the noble metallic NPs contain excellent physical/ chemical and surface charge properties. These kinds of exclusive properties prefer the metallic NPs, especially $\mathrm{Au} / \mathrm{Ag} / \mathrm{Pd}$ as a potential and significant therapeutic agent for biological treatment (Rai et al., 2013). Metallic NPs (Au/Ag/Pd) are considered as a potential source for biomedical applications which contain the most effective properties such as highly stable aggregate activities, non-toxic, biocompatible, specific to target cells and tissues and very easily available. A brief outline of $\mathrm{Au} / \mathrm{Ag} / \mathrm{Pd}$ is summarized below.

\section{GOLD NANOPARTICLES}

\section{Cancer, Antibacterial, and HIV Treatment}

The AuNPs have received much attention due to their benchmark properties. They have been studied as a potential source for the treatment and diagnosis of cancerous cells, anti-bacterial activity, AIDS, drug delivery, and bioimaging therapy. Furthermore, the non-immunogenic and non-toxic nature of AuNPs with high permeability and the high retention effect suggest further support of the informal accumulation and penetration for the treatment of tumor sites. Several advanced methods of AuNPs are still under development due to its distinctive values in the therapeutic field
(Kumar et al., 2011; Di-Gianvincenzo et al., 2012; Her et al., 2017; Kim, 2019). AuNPs formerly played a substantial part in human welfare in the clinical diagnostic field as well as numerous medical applications. Further advanced research demonstrates that AuNPs are becoming attractive and the most promising method in cancer, anti-bacterial and AIDS treatment. The shape, size, surface coating, functionalization, and interaction of AuNps has been demonstrated in Figure 1. However, the application of AuNPs in the advancement of nanotechnology is the most incredible and highly promising in the treatment of cancer cells.

The AuNPs applications in various biomedical techniques such as X-rays/ CT bioimaging, photoacoustic imaging, chemical sensing, photothermal, radiation therapy and drugs delivery has also been studied as shown in Figure 2.

AuNPs have been stated as the most active antibacterial agents as shown in the literature, Table 1. The green synthesized AuNPs actively work against Corynebacterium pseudotuberculosis, these bacteria cause a serious bacterial infection which is commonly found in sheep (Huang et al., 2011a; Mohamed et al., 2017). The antibacterial activities of AuNPs are significant due to the better penetration ability through the cell wall of the target body. Zhou et al. (2012) stated that AuNPs suppressed E. coli growth. Li et al. (2014) studied the functionalized AuNPs as a most efficient and active medium against gramnegative and gram-positive multi-drug resistance pathogens. The

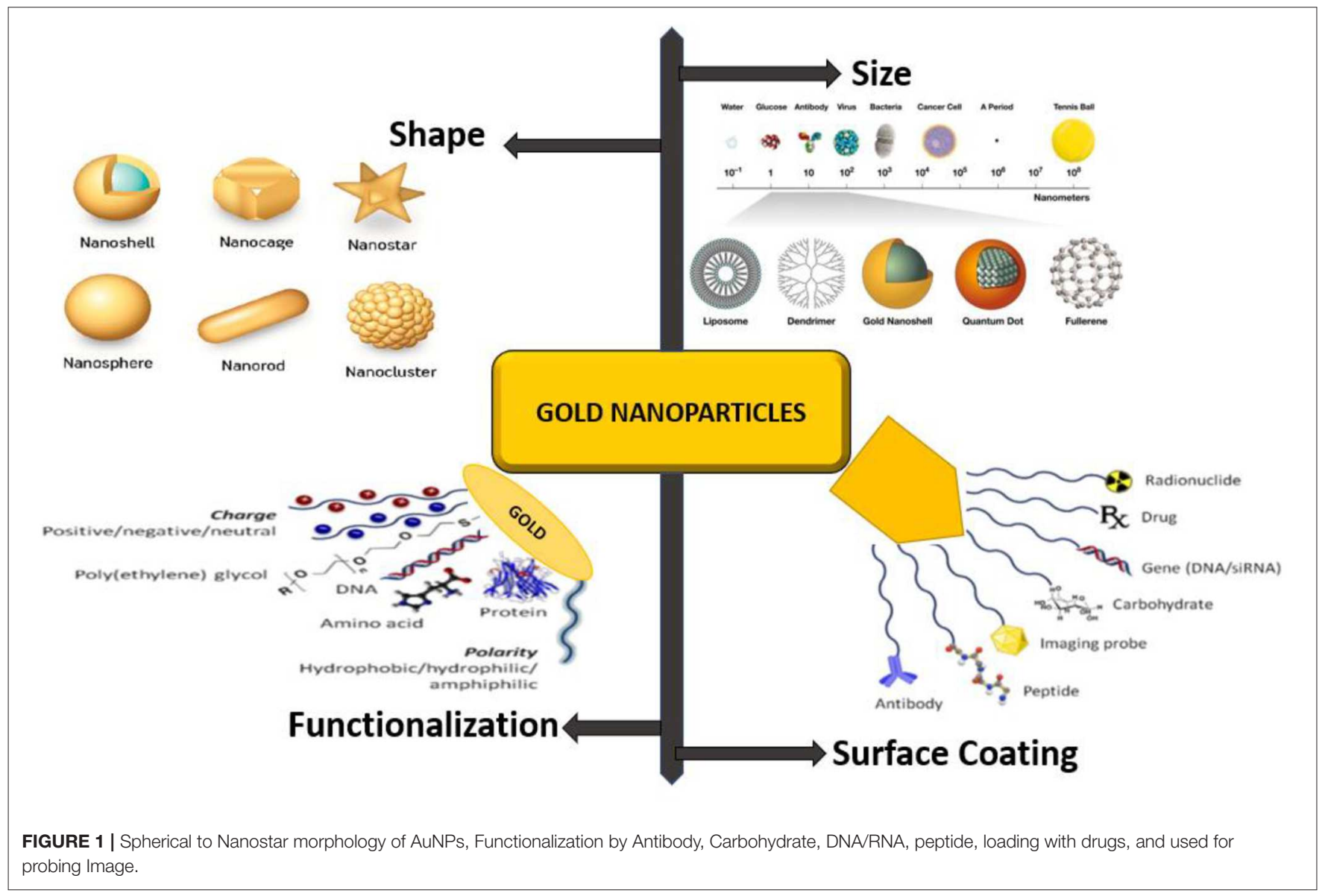




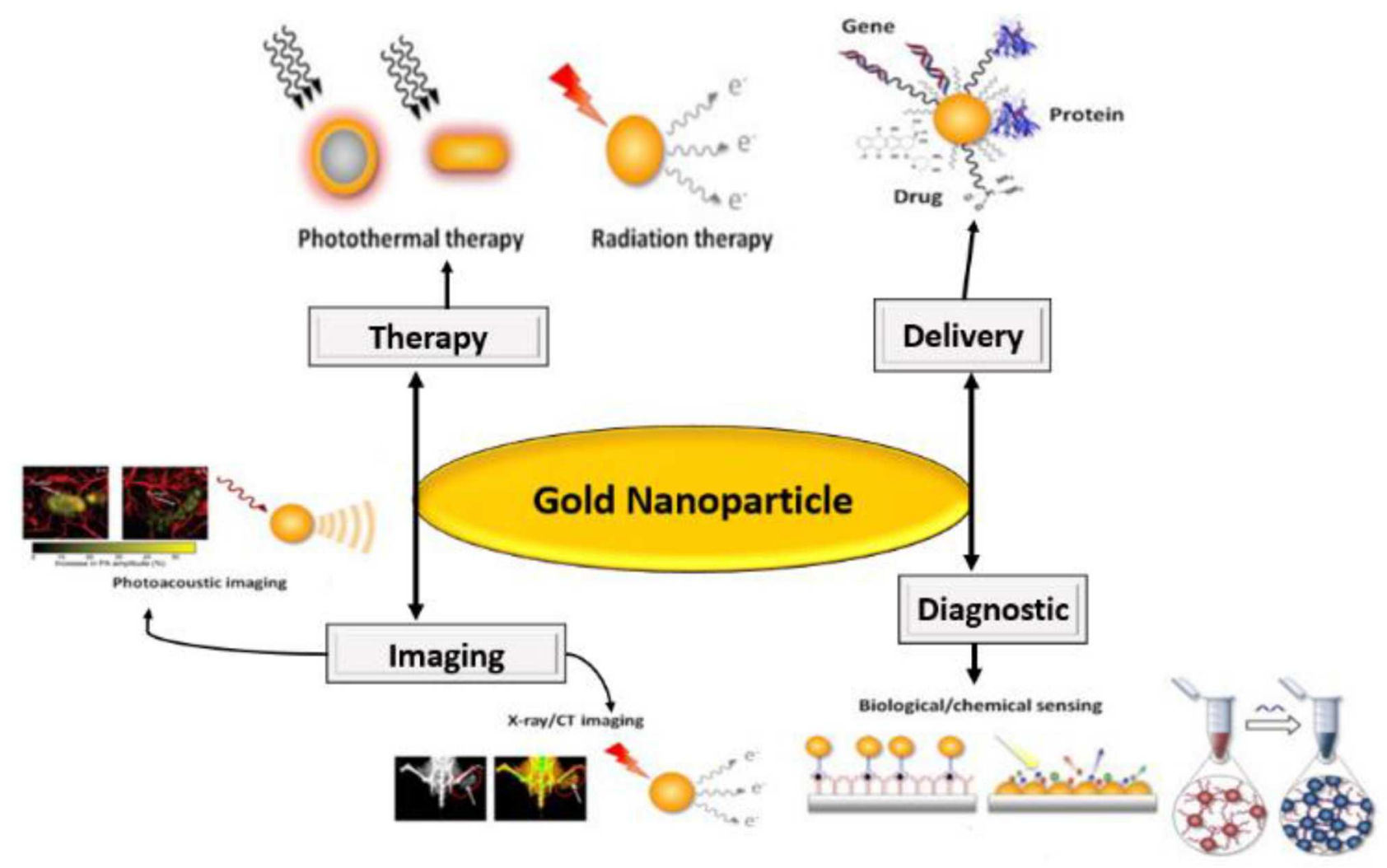

FIGURE 2 | Application of AuNPs in medicinal science.

cationic hydrophobic AuNPs were active toward the bacterial cell membrane integrity and produced instability in the bacterial cells. AuNPs showed a slightly toxic effect on the mammalian body cells. Antibacterial activities of AuNPs against grampositive and negative bacteria are not similar due to bacterial membrane structure which is recommended for the high dose of NPs. AuNPs antibacterial activities occur due to the condensed adenosine triphosphate synthase activity that disturbs the basic process of metabolism and distorts the ribosome units for tRNA binding, therefore, a failure of bacterial biotic mechanism occurs. The large surface area of AuNPs improves the interaction with bacterial cells (Shamaila et al., 2016). The AuNPs affect bacterial cytoplasm and protein that cause cell death. AuNPs, when combined with antibiotics, offered enhanced antibacterial activities. Certain antibiotics have been employed such as kanamycin, gentamicin, vancomycin, ampicillin, streptomycin, and levofloxacin. The AuNPs did not show antibacterial activities, though they served as a drug transporter for gentamicin distribution due to their large surface area (Dasari et al., 2015). The antibacterial activities of AuNPs were not substantial when likened with gentamicin. Saha et al. (2007) collectively studied AuNPs with kanamycin, streptomycin, and ampicillin. The combinations were quite active against Micrococcus luteus, E. coli, and Staphylococcus aureus. AuNPs, when shared with kanamycin and streptomycin presented considerable antibacterial activities. The insignificant antibacterial activities of AuNPs along with ampicillin has exposed poor stability, though the free AuNPs did not show antibacterial activities. AuNPs when not combined with antibiotics is unproductive against powerful bacteria. Therefore, they serve as medication carriers and their mixture with antibiotics results in synergistic antibacterial actions. AuNPs are steady and their capacity to interrelate with bacterial cells empowers them as a significant antibacterial agent (Santhoshkumar et al., 2014).

The AuNPs exhibited better antiviral activities when permitted to interrelate with the virus. The preparation at the absorption of 2 or $4 \mathrm{ppm}$ was further active for hindering the viral access. AuNPs served as a virus entrance inhibitor and as a deactivating agent. Chiodo et al. (2014) described carbohydrate-doped AuNPs which are conjugated along with nucleoside opposite transcriptase inhibitors called lamivudine. AuNPs reserved HIV viral duplication in-vitro parallel to drugs. The distribution of applied-medicine from AuNPs repressed viral duplication thus dismissing the development of viral DNA. Currently, there are inadequate investigation studies on AuNPs applications for herpes infections. Sarid et al. (2014) designed sulfonate-covered hydrophilic AuNPs for the inhibition of herpes infections. AuNPs interrelated with the virus through preventing virus-related accessory and dispersion into the cells, thus avoiding infections. Nanotechnology's applications for the 
TABLE 1 | AuNPs antibacterial activity with their therapeutic influence.

\begin{tabular}{|c|c|c|c|}
\hline Metal nanoparticles & Type of bacteria & Therapeutic effect & References \\
\hline AuNPs & $\begin{array}{l}\text { Corynebacterium } \\
\text { pseudotuberculosis }\end{array}$ & Effectively work against bacterial infection & Shaikh et al., 2019 \\
\hline AuNPs & E. coli & Actively work against $E$. coli & Zhou et al., 2012 \\
\hline AuNPs & E. coli & $\begin{array}{l}\text { NPs were vigorous against Gram- positive, } \\
\text { Gram- negative multi-drug resistant pathogens }\end{array}$ & Li et al., 2014 \\
\hline AuNPs & $\begin{array}{l}\text { E. coli, Staphylococcus } \\
\text { aureus, Bacillus subtilis and Klebsiella } \\
\text { pneumonia }\end{array}$ & Active against bacterial infection & Shamaila et al., 2016 \\
\hline AuNPs & $\begin{array}{l}\text { E. coli, S. typhimurium DT104, and S. } \\
\text { aureus }\end{array}$ & Actively work against bacterial infection & Dasari et al., 2015 \\
\hline AuNPs & Salmonella typhi & Actively inhibited the bacterial growth & Lima et al., 2013 \\
\hline AuNPs & Staphylococcus aureus and E. coli & $\begin{array}{l}\text { Active against Staphylococcus aureus and } \\
\text { Escherichia coli }\end{array}$ & MubarakAli et al., 2011 \\
\hline $\begin{array}{l}\text { AuNPs shared properties } \\
\text { with ampicillin }\end{array}$ & $\begin{array}{l}\text { E. coli, Micrococcus luteus and } \\
\text { Staphylococcus aureus }\end{array}$ & Actively work against the bacteria & Saha et al., 2007 \\
\hline AuNPs collective properties with streptomycin & $\begin{array}{l}\text { E. coli, Micrococcus luteus and } \\
\text { Staphylococcus aureus }\end{array}$ & Potentially work against the bacteria & Saha et al., 2007 \\
\hline $\begin{array}{l}\text { AuNPs shared properties } \\
\text { with kanamycin }\end{array}$ & $\begin{array}{l}\text { E. coli, Micrococcus luteus and } \\
\text { Staphylococcus aureus }\end{array}$ & Potentially work against the bacteria & Saha et al., 2007 \\
\hline AuNPs collective properties with levofloxacin & S. aureus and E. coli & Inhibited the bacterial growth & Bagga et al., 2016 \\
\hline $\begin{array}{l}\text { AuNPs shared properties } \\
\text { with vancomycin }\end{array}$ & - & $\begin{array}{l}\text { Selectively bind the cells of Gram-positive and } \\
\text { negative Bacteria, Antibiotic-resistant bacteria }\end{array}$ & Gu et al., 2003 \\
\hline $\begin{array}{l}\text { Light-absorbing AuNPs conjugated with } \\
\text { precise antibodies }\end{array}$ & Staphylococcus aureus & Selective killing of bacterium & Zharov et al., 2006 \\
\hline $\begin{array}{l}\text { AuNPs shared properties } \\
\text { covered with cefaclor }\end{array}$ & Staphylococcus aureus, E. coli & $\begin{array}{l}\text { Effective antibacterial activities against } \\
\text { Gram+ive and Gram-tive bacteria }\end{array}$ & Zhang et al., 2015 \\
\hline $\begin{array}{l}\text { AuNPs shared properties } \\
\text { with gentamicin }\end{array}$ & Active against Escherichia coli & & Rai et al., 2019 \\
\hline AuNPs combined with gentamicin & - & Excellent antibacterial activities & Burygin et al., 2009 \\
\hline $\begin{array}{l}\text { AuNPs synthesize by using Stoechospermum } \\
\text { marginatum }\end{array}$ & - & Improved antibacterial activities & Rajathi et al., 2012 \\
\hline $\begin{array}{l}\text { AuNPs synthesize through using aqueous } \\
\text { moringa oleifera leaves }\end{array}$ & Staphylococcus aureus & Effective against bacterium & $\begin{array}{l}\text { Prasad and Elumalai, } \\
2011\end{array}$ \\
\hline AuNPs synthesize from A. comosus extract & - & $\begin{array}{l}\text { Useful decontamination methods for inhibiting } \\
\text { the bacterial growth }\end{array}$ & $\begin{array}{l}\text { Bindhu and Umadevi, } \\
2014\end{array}$ \\
\hline AuNPs Synthesize by using with ofloxacin & - & Greater bactericidal property & Ahmed et al., 2014 \\
\hline $\begin{array}{l}\text { AuNPs Synthesize by using banana peel } \\
\text { extract }\end{array}$ & - & Improved antibacterial activity & Bankar et al., 2010 \\
\hline
\end{tabular}

cancer cell treatment are based on primary tumor exposure and the analysis by Nano-devices accomplished of selective point and the distribution of chemotherapeutic treatments to definite tumor position. The notable properties of AuNPs are measured as a substantial source for the analysis of different cancerous cells. Presently, the chemotherapeutic treatment depends on the typical chemo and radiation therapies, with the purpose to execute the cancerous cells. Moreover, these actions may result in numerous adjacent side effects due to mutilation caused to the immediate healthy tissues, interruptions in the analysis (Baram-Pinto et al., 2010). Treating the cancerous cells by employed Nano-range drug deliveries method plays a significant part in disabling the restrictions of predictable action methodologies by offering instantaneous diagnostics (Rashid and Ahmad, 2019). Therefore, a substantial volume of study focuses on the nanocarrier growth of AuNPs and their possible sustainable applications in cancerous biology. The bioinspired AuNPs have become a potential possibility to discover for use in biosensors, targeted drug delivery, photothermal therapies, immunoassays, photoimaging, and photodynamic therapy as shown in Figure 3. Interestingly, in human cancerous and cellular biology, several kinds of AuNPs such as Au nanorods, $\mathrm{Au}$ nanocages, $\mathrm{Au}$-stars, nano Au-cubes, and Au nanospheres, have been considered as effective tools (Das et al., 2019; Filli et al., 2019; Pillai, 2019; Shrivastava et al., 2019). Despite all these assistances, the biocompatibility of AuNPs is a vital factor to be reconsidered for the interpretation of scientific applications. The current role of AuNPs in the treatment and diagnosis of cancer cells, along with the biocompatibility, is discussed in Table 2. 
A

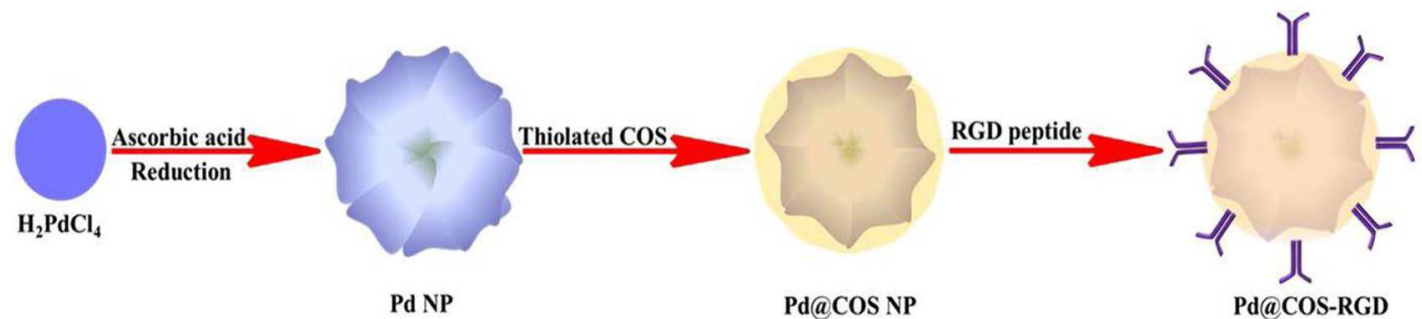

B

Pd NP

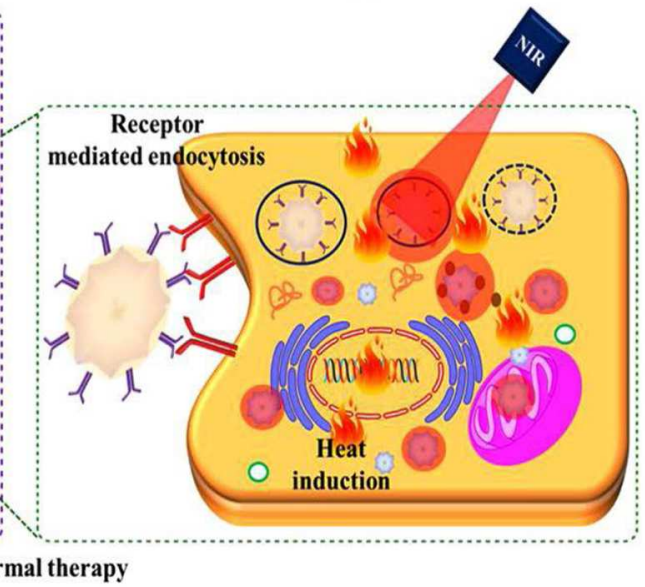

Photothermal therapy

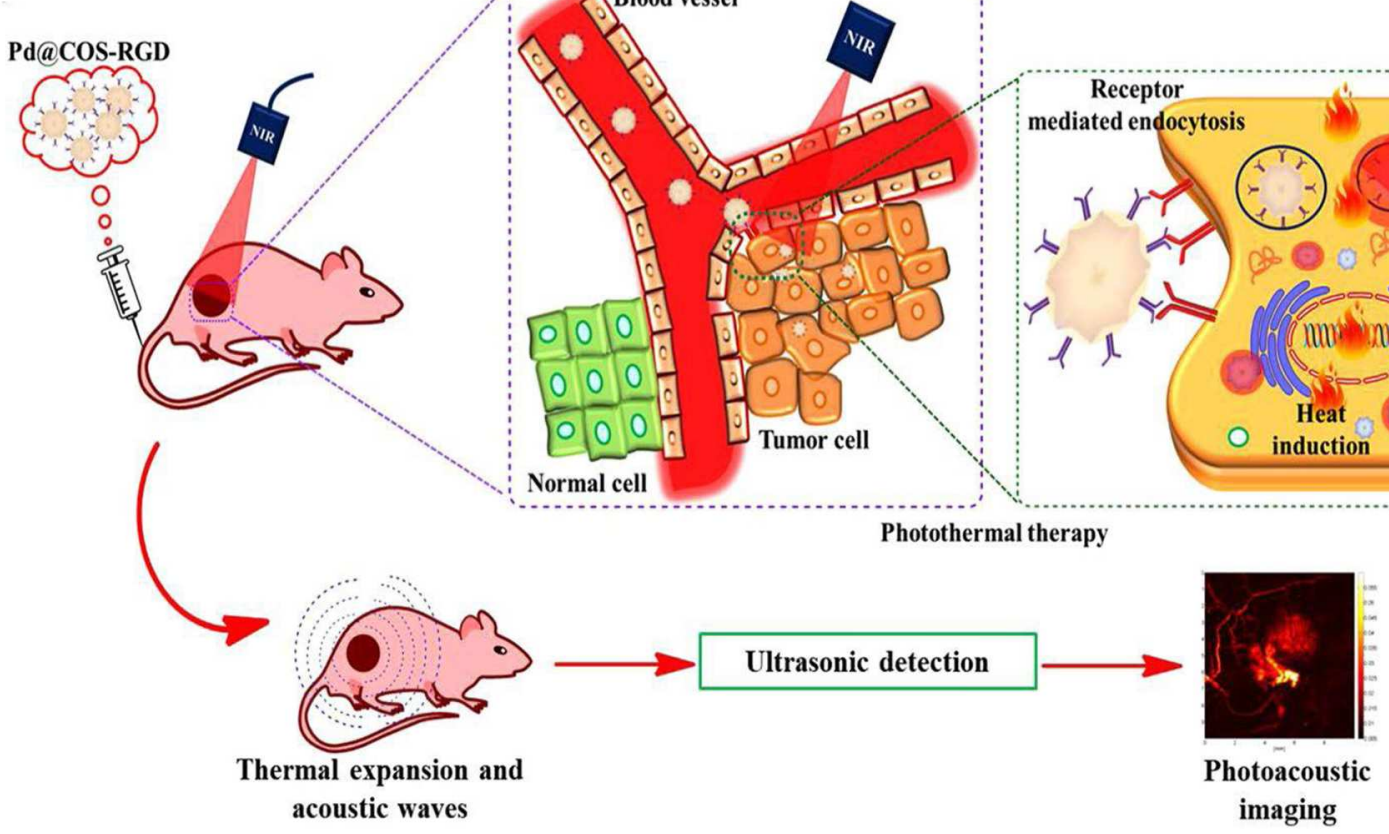

FIGURE 3 | (A) A systematic representation of preparation of PdNPs, functionalized by surface coating of thiolate chitosan oligosaccharide Pd@COS NPs and followed by functionalization with RGD peptide. (B) A schematic representation of Pd@COS-RGD showing the thotothermal ablation and photoacoustic imaging at tumor site [Adapted from (Bharathiraja et al., 2018), with permission of Springer Nature].

\section{GNPs as an Inhibitor of HIV, Cancer Vaccines}

The immune system of our body is capable of removing some viral infections itself. However, some of the infections such as herpes, hepatitis, HIV, are long-lasting, persistent, and cannot be removed. AuNPs are used as a delivery scheme for the improved effectiveness of anti-HIV activity. The free AuNPs are unproductive against HIV infection. Kesarkar et al. (2012) found that stabilized AuNPs in amino acid L-cysteine resulted in the enhanced azidothymidine delivery against the HIV-1Ba-L virus in-vitro. AuNPs are employed for the anti-HIV activities at the initial phase of virus-related replication. The anti-HIV activities of AuNPs are due to poly-anionic shallow that allows the binding with positively charged amino acids at the binding position of glycoprotein gp120, the mechanism of inhibition takes place and the AuNPs block the reverse transcriptase enzyme of HIV1 proteins. Garrido et al. (2015) studied conjugated AuNPs with better HIV activities. Free AuNPs did not show anti-HIV activities. Kesarkar et al. (2012) also studied the coated AuNPs through polyethylene glycol.
Rich and Miszka (2000) studied the role of oligiomannoside as an inhibitor of gp120 binding to 2G12, using the Surface plasmonon Resonance (SPR) technique for molecular interactions. SPR makes a significant contribution to understand the molecular basis of the HIV life-cycle; mannose-GNPs act as an inhibitor of gp120 binding to DC-SIGN (Martinez-A' vila et al., 2009). Marradi et al. (2011) demonstrated the ability of mannose-GNPs to bind $2 \mathrm{G} 12$ and to inhibit 2G12/gp120 binding. The benefit of multivalent therapeutics of gold NPs transform a feeble binding and biologically inactive small molecule into a multivalent conjugate that acts precisely against the HIV-1 fusion to human T-Cells (Bowman et al., 2008; Parry et al., 2013). The high degree of multivalences and the easily controllable size of GNPs provides a great significance for biological application. The carbohydrate-coated GNPs have an advantage of non-toxic environments (Goodman et al., 2004; Ojeda et al., 2007). Brinãs et al. (2012) demonstrated the design and synthesis of AuNPs with multifunctionality that were loaded with tumor-associated glycopeptide antigens and acted as a potential cancer vaccine. Cai et al. (2016) prepared 
TABLE 2 | AuNPs application in cancer cell diagnosis, treatment methods, and its advantages.

\begin{tabular}{|c|c|c|c|c|c|c|}
\hline $\begin{array}{l}\text { Metallic } \\
\text { nanoparticles }\end{array}$ & $\begin{array}{l}\text { Particle size } \\
\text { (nm) }\end{array}$ & Targeted & Cancer cells & Methods & Method performance & References \\
\hline AuNPs & 15 & $\begin{array}{l}\mathrm{pAb} \text { and } \mathrm{mAb} \\
\text { anti-CEA antibodies, }\end{array}$ & MCF7 cells & SERS immunoassay & $\begin{array}{l}\text { Different immunoassay } \\
\text { method }\end{array}$ & Chon et al., 2009 \\
\hline AuNPs & 35 & anti-EGFR & $\begin{array}{l}\text { Oral epithelial living } \\
\text { Cancerous cell }\end{array}$ & SPR & Valuable molecular sensors & $\begin{array}{l}\text { El-Sayed et al., } \\
2005\end{array}$ \\
\hline AuNPs & 20 & Heparin & Epithelial & Imaging & therapeutics and Imaging & Shi et al., 2007 \\
\hline AuNPs & - & $\begin{array}{l}\text { folic acid, } \\
\text { fluorescein } \\
\text { isothiocyanate }\end{array}$ & Liver cells-imaging & Imaging & Possible CT imaging & Sun et al., 2009 \\
\hline AuNPs & 15 & $\begin{array}{l}\text { Functionalized shiny } \\
\text { carbon electrodes }\end{array}$ & Lung and liver cancer, & $\begin{array}{l}\text { Electrochemical and } \\
\text { contact-based } \\
\text { angle measurements }\end{array}$ & $\begin{array}{l}\text { Fast identification and vastly } \\
\text { sensitive exposure } \\
\text { for cancerous cell }\end{array}$ & He et al., 2009 \\
\hline AuNPs & 30 & ENO1 antibodies & Lung cancer & $\begin{array}{l}\text { Electrochemical immune } \\
\text { sensor }\end{array}$ & $\begin{array}{l}\text { Measurable tests protein } \\
\text { and cancerous biomarkers }\end{array}$ & Ho et al., 2010 \\
\hline AuNPs & 100 & $\begin{array}{l}\text { Anticarcinogen-embryonic } \\
\text { antibodies }\end{array}$ & Cancer & ELISA & $\begin{array}{l}\text { Premature diagnosis of } \\
\text { cancer }\end{array}$ & Zhou et al., 2011 \\
\hline AuNPs & 20 & $\begin{array}{l}\text { kinase } \mathrm{C}(\mathrm{PKC} \text {-alpha) } \\
\text { peptides }\end{array}$ & Breast cancer & GNP- colorimetric assay & $\begin{array}{l}\text { Preliminary screening } \\
\text { throughout cancer } \\
\text { diagnosis }\end{array}$ & $\begin{array}{l}\text { Raghavendra } \\
\text { et al., } 2014\end{array}$ \\
\hline AuNPs & 15 & $\begin{array}{l}\text { anti-CA15-3-HRP } \\
\text { antibodies }\end{array}$ & Breast cancer & ELISA & Detection of cancerous cells & $\begin{array}{l}\text { Ambrosi et al., } \\
2009\end{array}$ \\
\hline AuNPs & 90 & $\begin{array}{l}\text { EGF-ligand and tag } \\
\text { Raman receptors }\end{array}$ & Flow tumors & SERS & $\begin{array}{l}\text { Novel clinical device for } \\
\text { managing of patients }\end{array}$ & Wang et al., 2011 \\
\hline AuNPs & 25 & anti-EGFR & Paracervical cancer & Illumination microscopy, & $\begin{array}{l}\text { Influential device for } \\
\text { detecting cellular, molecular } \\
\text { variations }\end{array}$ & $\begin{array}{l}\text { Rahman et al., } \\
2005\end{array}$ \\
\hline AuNPs & 15 & Single-chain variable part & Oral cancer & SERS & $\begin{array}{l}\text { Saliva-assay for initial } \\
\text { analysis of oral Cancerous } \\
\text { cells }\end{array}$ & Kah et al., 2007 \\
\hline AuNPs & 60 & anti-EGFR & Head-and-neck & SERS & $\begin{array}{l}\text { Optical and EM enquiries for } \\
\text { tumor detection }\end{array}$ & Conde et al., 2012 \\
\hline AuNPs & 45 & Her-2/neu antigen & Prostate cancer detection & $\begin{array}{l}\text { Difference photoacoustic } \\
\text { imaging }\end{array}$ & $\begin{array}{l}\text { Filmic device for molecular } \\
\text { and structural information }\end{array}$ & $\begin{array}{l}\text { Agarwal et al., } \\
2007\end{array}$ \\
\hline AuNPs & 15 & $\begin{array}{l}\text { F19 monoclonal } \\
\text { antibodies }\end{array}$ & Pancreatic adenocarcinoma & $\begin{array}{l}\text { Light sprinkling, size } \\
\text { prohibiting chromatography }\end{array}$ & Labeling method & Eck et al., 2008 \\
\hline AuNPs & 20 & Aptamer & $\begin{array}{l}\text { Leukemia and } \\
\text { lymphoma }\end{array}$ & Spectroscopic method & $\begin{array}{l}\text { Primary and precise } \\
\text { exposure of cancer }\end{array}$ & Medley et al., 2008 \\
\hline
\end{tabular}

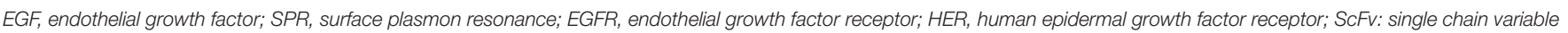

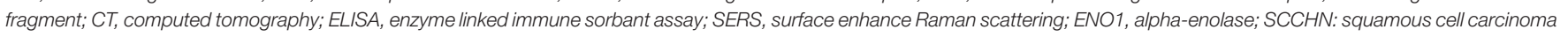
of the head and neck; PC-3, prostate cancer cells; pAb, polyclonal antibody; mAb, monoclonal antibody; PEG, poly ethylene glycol; CEA, carcinoembryonic antigen.

the anticancer vaccines from AuNPs-based vaccines against the tumor-associated form of the mucin-1 glycoprotein.

\section{SILVER NANOPARTICLES}

\section{A Remedy for Antibacterial and Viral Diseases}

The researchers have stated the importance of AgNPs in the treatment of different diseases as shown in Table 3. AgNPs interrelate with microbes and discharge the silver ion in the de-activation of cellular-based enzymes, delayed membrane penetrability. Several scholars have highlighted the antibacterial activities through AgNPs (Adetunji, 2019; Tyagi and Kumar, 2019), mode of action against bacterial germ and cellular-based antimicrobial activities.
AgNPs are also active significant therapeutics for HIV infection treatment (Lara et al., 2010) defined the status of AgNPs as an anti-HIV at the initial phase of viral duplication and later phases of the HIV-life cycle. AgNPs serve through the binding process to gp120, then subsequent inhibition of CD4-reliant on binding, blend, and infection, though the antiviral approach of AgNPs is not entirely understood yet. Herpes disease is a sickness produced by herpes virus HSV-1 and HSV-2. The HSV2 is related to sexually spread diseases. AgNPs are very active to prevent the development of this virus at both pre and post stages (Sun et al., 2005; Marambio-Jones and Hoek, 2010). Contact between AgNPs and HSV-2 has caused a substantial decrease in the posterity of viruses with feeble cytotoxicity in-vitro. AgNPs bond with the glycoprotein membrane of HSV-2, resulting in the contact that delayed virus internalization. This is due to the interfacial glycoprotein and their ability to act as a receptor. 
TABLE 3 | AgNPs function in the treatment of infections.

\begin{tabular}{|c|c|c|c|}
\hline Nanoparticles & Nature of infection & Therapeutic conclusion & References \\
\hline \multirow[t]{9}{*}{ AgNPs } & Malaria & Prevention of growth of $P$. falciparum & Murugan et al., 2016 \\
\hline & Leishmaniasis & $\begin{array}{l}\text { Limitation of proliferation and metabolic activities of } \\
\text { promastigotes. }\end{array}$ & Zahir et al., 2015 \\
\hline & Helminth infections & Improved anthelmintic activities in contradiction of worm & Nadhman et al., 2016 \\
\hline & HIV & $\begin{array}{l}\text { Inhibition of CD4-based virion binding, fusion, and } \\
\text { infection }\end{array}$ & Elechiguerra et al., 2005 \\
\hline & Herpes & Virus duplication was reserved & Hu et al., 2014 \\
\hline & Herpes & $\begin{array}{l}\text { Reserve of viral access into cell and inhibition of ensuing } \\
\text { infection }\end{array}$ & Baram-Pinto et al., 2009 \\
\hline & Hepatitis & $\begin{array}{l}\text { Interface with the HBV viral units subsequent in reduction } \\
\text { of production of HBV RNA and extra-cellular }\end{array}$ & Lara et al., 2011 \\
\hline & Influenza & Active against influenza viruses & Rafiei et al., 2018 \\
\hline & Influenza & Active against influenza A virus & Taubenberger and Morens, 2008 \\
\hline $\begin{array}{l}\text { AgNPs synthesize through biological } \\
\text { approaches by using fungi, algae, bacteria and } \\
\text { virus }\end{array}$ & Bacterial infection & Excellent antibacterial activities & Shirley et al., 2010 \\
\hline $\begin{array}{l}\text { AgNPs and amoxicillin, azithromycin, } \\
\text { clarithromycin, linezolid, or vancomycin }\end{array}$ & Bacterial infection & $\begin{array}{l}\text { Better synergistic antibacterial effects against } \\
\text { methicillin-resistant }\end{array}$ & Akram et al., 2016 \\
\hline AgNPs and gentamicin and penicillin & Bacterial infection & $\begin{array}{l}\text { Exceptional antibacterial properties against animal } \\
\text { bacterial infections, }\end{array}$ & Smekalova et al., 2016 \\
\hline $\begin{array}{l}\text { AgNPs mixture with lactam; } \\
\text { quinolone; aminoglycoside and polykeptide }\end{array}$ & Bacterial infection & $\begin{array}{l}\text { Active against drug-resistant bacteria Salmonella } \\
\text { typhimurium. }\end{array}$ & Deng et al., 2016) \\
\hline AgNPs mixture with amoxicillin & Bacterial infection & Excellent synergistic effects against $E$. coli & Li et al., 2005 \\
\hline $\begin{array}{l}\text { AgNPs shared with polymyxin B } \\
\text { and rifampicin }\end{array}$ & Bacterial infection & $\begin{array}{l}\text { High synergistic effects against Acinetobacter, baumannii } \\
\text { infection. }\end{array}$ & Srinivasan et al., 2006 \\
\hline AgNPs in urinary catheter & Bacterial infection & $\begin{array}{l}\text { Active NPs against bacteria that are answerable for } \\
\text { urinary tract infections. }\end{array}$ & Wan et al., 2016 \\
\hline Nanowires of AgNPs & Bacterial infection & $\begin{array}{l}\text { Nano-cube AgNPs showed the highest antibacterial } \\
\text { activities. }\end{array}$ & Romaniuk and Cegelski, 2015 \\
\hline Hexagonal and nanoplates AgNPs & Bacterial infection & $\begin{array}{l}\text { Hexagonal-shaped AgNPs were actual against S. aureus } \\
\text { and E. coli }\end{array}$ & Hong et al., 2016 \\
\hline Rod-shaped AgNPs & Bacterial infection & $\begin{array}{l}\text { Triangular shaped revealed high antibacterial activities } \\
\text { against } E \text {. coli }\end{array}$ & Pal et al., 2007 \\
\hline
\end{tabular}

Tannic acid has improved the AgNPs which could reduce the HSV-2 contamination both in-vivo and in-vitro (Elechiguerra et al., 2005; Huang et al., 2018; Verma and Maheshwari, 2019). The antiviral activities of AgNPs were designed through the fractional particle size and dose formulation. AgNPs affect hepatitis $\mathrm{B}$ which has been described earlier with the particle size of 10-50 nm. The in-vitro anti-HBV assessment of these units on the Hep AD38 cell line exposed that the AgNPs have condensed the extra-cellular HBV. AgNPs interacted with the HBV virusrelated particles and caused a reduction of $\mathrm{HBV}$, RNA production and extracellular virus. Helminth infections are measured by tropical desert diseases (Bai et al., 2018; Khatami et al., 2018). The helminth is dependent on worms which are like invertebrate, extended, smoothed or flatforms. AgNPs are also control the infection caused by helminth. AgNPs are very active in the biotreatment of several types of contaminations such as bacterial, viral and parasitic and work as active meditators (Alam et al., 2017). The biosynthesized self-dispersed AgNPs prepared from the extract of $P$. peruviana acted as a chemical sensor for the dl-alanine amino acid (Rashid and Sabir, 2014; Rashid et al., 2016).

\section{PALLADIUM NANOPARTICLES}

Pd is a very precious metal with extraordinary catalytic, powerful mechanical, and electroanalytical properties. Pd nano-based structures have been developed as self-therapeutics, with proven anti-bacterial and cytotoxic pharmacological activity. Adams et al. (2014) studied the PdNPs' size-based antibacterial activities. The PdNPs showed high growth prevention against S. aureus, as compared to another bacterial species called E. coli, the importance of PdNPs is valuable against the anti-bacterial agent, particularly for gram-positive microbes. Sachse et al. (2013) described that the PdNPs fabricated on mesoporous silica nanomaterials showed moderately higher cytotoxic activities against human cancer cell lines. Fascinatingly, these fusion materials also exhibited catalytic activities and were employed for carbon-carbon bonds through Suzuki-Miyaura cross-coupling amongst minor molecules. If PdNPs are the stimulating agent as a self-therapeutics, the additional research is required to clarify their mechanism before they could be used appropriately as a nanomedicines (Dumas and Couvreur, 2015). Taking the benefit of metallic catalytic and optical features, the significant 
therapeutic-based applications have involved three courses of Pd nanostructures as shown in Figure 3.

Metallic nanostructures facilitated the photothermal (PT) therapies that have invited wide attention recently. The nanotechnology relies on the photon energy absorption, through after the absorption of energy tumor-confined nanostructures that kill the nearby cells. For this persistence, the utilization of near-infrared (NIR) light is the basis usually desired. Au nanostructures are extensively applied in the PT therapy mediators due to their higher destruction co-efficient in the NIR area, higher PT adaptation efficiency and adequate biocompatibility (Xiao et al., 2014; Dumas and Couvreur, 2015; Wei et al., 2015). The PdNPs were not measured as an effective PT mediators until Huang et al. (2011b); and Stone et al. (2016), with an ultra-thin range of $1.8 \mathrm{~nm}$, and hexagonal PdNPsbased sheets that show the well-organized size-dependent and tenable absorption points in the NIR zone with resourceful PT conversion. The Nano-sheets of $41 \mathrm{~nm}$ range were employed to kill the liver-based cancer cells and irradiated with $808 \mathrm{~nm}$ laser light that shows the higher biocompatibility. Interestingly, these nano-sheets display healthier photo-stability when associated with Au/Ag nanostructures (Huang and Juang, 2011; MendozaPérez and Guisbiers, 2019).

\section{MECHANISM OF TOXICITY}

The physical and chemical reactivity can be a source of formation for free radicals or reactive oxygen species (Gahlawat and Choudhury, 2019; Valavanidis, 2019). The superoxide anionsbased radical, and hydroxyl-based radicals, directly or indirectly affect the oxidation of enzymatic pathways, resulting in a form of oxidative stress. The oxidative stress is caused by any of following the reason (Fard et al., 2015)

i. Oxidant produced properties of NPs themselves in addition to their ability to produce reactive oxygen species (ROS) as a fragment of cells response to NPs

ii. Noble metal-based NPs or metal impurities employed as catalysts throughout the generation of non-metal NPs.

iii. Free radical intermediates exist on surfaces of NPs that are the most reactive.

iv. Redox vigorous clusters from NPs functionalization (Montalvo-Quiros and Luque-Garcia, 2019).

\section{Cytotoxicity of Au/Ag/Pd Nanoparticles}

AuNPs are the most capable and precious inorganic-based NPs which have attracted a lot of technical and scientific attention due to the presence of significant synthesis methods, better biochemical constancy, and the outstanding optical features. These exclusive topographies of AuNPs refer to them as an interesting approach for cancerous cell diagnosis and action. The in-vitro studies have revealed that the AuNPs are less toxic for cellular systems. Cytotoxicity assessment of AuNPs is important because of the wide-ranging variety-based application of AuNPs in the medical field (Khlebtsov and Dykman, 2011; Heo et al., 2012; Fard et al., 2015). In the literature, it has been demonstrated that some inorganic NPs are almost intolerant to the toxicity. The cytotoxicity depends on shape, size and adjacent ligands. Some studies showed that globular AuNPs are appropriate for medical applications (Taylor et al., 2012). The cytotoxicity effect from 5 to $15 \mathrm{~nm}$ AuNPs, invitro on Balb/3T3 mouse fibro-blasts have been examined. To comprehend the experiential alterations in different sized AuNP's cytotoxicity, Coradeghini et al. (2013) observed the acceptance and outside relation of cellular circulation of NPs. There are toxic effects for cellular treatment with $5 \mathrm{~nm}$ AuNPs, but no toxic effect is exposed to Balb/3T3. This reflection occurs due to the quantity of $5 \mathrm{~nm}$ AuNPs taken-up through cellular evaluation of the larger particle size. Similarly, in the case of AgNPs, antimicrobial characteristics of AgNPs are the source of NP usage in a wide variety of customer products including cosmetics, microchip technology, domestic appliances, fabric material, and nutrition products. Currently, AgNPs have been employed in biomedical fields like drug delivery, manipulative biosensing, and bioimaging, etc. Therefore, the toxicity assessment is of significant importance that is measured in many applications for medical resolutions (Chaloupka et al., 2010). The cytotoxicity of AgNPs is connected to the relaxed oxidation of $\mathrm{Ag}+$ ions which are toxic for biotic systems and the cell components. Gliga et al. (2014) found that the AgNPs in an aqueous culture is toxic and it is associated with the bulk AgNPs. Recently, whether the toxicity of AgNPs depended on coating and size was examined. The toxicity of NPs of $10 \mathrm{~nm}$ size was not dependent on the surface coating. In distinction, AgNPs produce a rise in the inclusive DNA injury after $24 \mathrm{~h}$ that recommends the self-regulating pieces of machinery for the toxicity and DNA harm. Though there was no enlarged intracellular ROS production, consequently, the toxicity is examined which is associated with the rate of intracellular release of Ag (Batchelor-McAuley et al., 2014). Contact with amino and thiol groups of molecules and the presence of toxicity on the cell components is a consequence of Ag release. Hence, AgNPs with increased Ag release is more deadly (Yang et al., 2011; Wang et al., 2012). PdNPs are usually employed in catalytic applications, where it can be discharged into the ecology through abrasion. These PdNPs may be moved into the surface of the water, with no data approximating their toxicity in the water system. Gurunathan et al. (2019) studied the particle size growth of PdNPs; with hydrodynamic $70 \mathrm{~nm}$ particles in media culture with the adjustable ionic asset. The PdNPs agglomerated extra fast with cumulative ionic strength, it produced a solitary marginal influence in an equally assessed species after $96 \mathrm{~h}$ of contact. Considering the lower ecological concentration of $\mathrm{Pd}$ in the superficial water that is usually $\mathrm{ng} / \mathrm{L}$, however, this results in a lower marine hazard in response to the PdNPs. Despite the inclusive applications of NPs in several areas of science, there are frequent remarks about the antagonistic effects of NPs on the biotic systems and cell partitions. Furthermore, the physicochemical activities, toxic ions production, structure of fibrous, higher surface charges, radical species generation, all result in toxicity through Ag/Au/Pd NPs (Leso et al., 2019). The condition of in-vivo/in-vitro assessments are employed to evaluate the harmfulness of nanomaterials. The in-vitro assessments have 
acknowledged the extra considerations associated with in-vivo, due to closer, non-suitable, and the absence of ethical issues (Shubha et al., 2019).

\section{Quantitative Toxicity Analysis}

Factors such as surface modification, size, concentration and the dose of NPs contributes to the bio distribution and toxicity under in-vivo and in-vitro conditions. The general sites of accumulation and biodistribution for AuNPs and AgNPs are liver, spleen (Van der Zande et al., 2012; Cui et al., 2018). The NPs primarily affect the mononuclear phagocyte system of these organs. The extra dose of AgNPs are deposited and stored in heart, lungs and kidneys whereas AuNPs are exclusively found in the liver. Another preferential site of AgNPs is blood and fecal matter. Yang et al. (2017) reported the toxicity and the biological distribution of AuNPs and AgNPs by intravenous administration of $11.4-13.3 \mathrm{mg} / \mathrm{kg}$ in mice. The administration of $5,10,45, \mathrm{mg} / \mathrm{kg}$ of AgNPs resulted in a decrease of body weight as examined by Zhang et al. (2013). However, the exposure to these NPs through oral administration or inhalation affect the growth of the organs. In the toxicity studies, the dose of the AuNPs/AgNPs is very significant for the biodistribution of these NPs in different tissues and body organs (Yang et al., 2017; Ma et al., 2020; Rodriguez-Garraus et al., 2020). To prevent the accumulation, there is no fully proven mechanism in the literature that discuss the removal of such NPs from the affected organs.

\section{FUTURE PROSPECT AND THE CONCLUDING REMARKS}

Metal-based NPs have been suggested to overcome the limitations of drug resistance. These metallic $\mathrm{Au} / \mathrm{Ag} / \mathrm{Pd} \mathrm{NPs}$ show positive cellular interactions with bio-molecules, both inside and on the surface of cells. They can also be applied by presenting designated biotic moieties through definite binding activities to a particular target and help in promoting their healing efficiency. Their outstanding cell contact has been used by many scholars to grow therapeutics for different viruses and for infectious diseases. Metallic NPs have been suggested to defeat co-viral contamination to increase the effectiveness of anti-viral medications, valuable for prophylactic, healing, diagnosis, photo thermal therapy, photoacoustic imaging, and laser therapy for cancer cells. Furthermore, there is insufficient information, demonstrating that there is a critical need for further research in designing of metallic-based NPs for viral infections treatment (Ngwa et al., 2014). Despite all applications of $\mathrm{Au} / \mathrm{Pd} / \mathrm{Ag} \mathrm{NPs}$, the most famous application is in the detection and treatment of tumor cancer cells, molecular bio-imaging, complex investigation, and immunoassay. Unfortunately, still, there is no absolute and complete treatment, protective vaccine or suitable analysis for cancer cells and AIDS. The AIDS/HIV disease exists in humans to an extent that is measured to be at the epidemic level. Moreover, in spite of the fast progress in the field, new cancerous cell cases have been silently cumulative.
Consequently, to promote the use of NPs widely in the biotic field, novel preparation, fabrication, and characterization approaches are desirable for the highly emerging and progressive field of nanotechnology (Bracey et al., 2009). To progress with biogenic NPs in diverse directions and their capability to modify the physical/chemical features, the NPs must possess the higher biocompatibility, high water dispersion, colloidal and physiological stability, making them more effective for treatment. However, sincere efforts are needed to minimize the toxicity level and to recover the non-invasive property so they can absorb the near-infra-red (NIR) light. The plasmonic property of NPs must not be compromised, thus, they can be effectively used in photothermal therapy and the imaging of tumor cells.

They can be better applied to make a more progressive and healthy binding affinity with several biomolecules and targeted drugs for treatment, detection of diseases such as cancer and HIV. In the future, it could be possible to employ these properties and to promote the green chemistry approach for the preparation of smart resources for diagnosis and their applications (Chesney, 2006). NPs hold excessive potential due to the anti-bacterial, anti-fungal, anti-viral, and anti-inflammatory characteristics, while the current study has mentioned the different osteoinductive features as well. The biological mechanisms and the relations behind these kinds of features are not entirely understood. For example, the association of AgNPs, shape, size and especially their biotic features and the cytotoxicity is not visibly studied. Therefore, additional study of AgNPs usage is needed for better outcomes. There is a persistent need to explain the concerning mechanism and the level of toxicity before the extensive biomedical application (Shubha et al., 2019). Despite their valuable chemical and physical features, PdNPs have been preoccupied with Nano-therapeutics collections. They also require an entire understanding of involved factors such as biodistribution and pharmacokinetics, metabolism mechanism, long-lasting toxicity, and mechanism of pharmacological activities (Barrabés and Sá, 2011). The interactions of nanostructures with cellular and biotic ecological is another matter that deserves a profound study, particularly the pre- and post-modification of NPs. The development of nanotechnology based on PdNPs with significant therapeutic characteristics is new, demonstrating only a few publications. Yet, their exclusive properties and significantly lower cytotoxicity means they are emerging key players in the Nano-medical field. Also, some innovative applications will be revealed through the usage of their optical properties for analysis, or extremely good-looking open-ended determinations (Lazarević et al., 2017). The several surfaces of Pd nanostructures provide modest systems that are able to accomplish many collective effects. Finally, overall, there is a crucial need to explore the toxicological properties and pharmaco-kinetics of metallic-based complexes. The medicines derived from organic compound show the drug resistance whereas metallic NPs have no such issues. There is no hesitation that these NPs are the most promising and emerging in the field of applied therapeutics. 


\section{AUTHOR CONTRIBUTIONS}

SY and RR wrote the draft of the article. MR designed the outline and revised the draft. RA did the final corrections in the manuscript.

\section{REFERENCES}

Adams, C. P., Walker, K. A., Obare, S. O., and Docherty, K. M. (2014). Sizedependent antimicrobial effects of novel palladium nanoparticles. PLoS ONE 9, 85-98. doi: 10.1371/journal.pone.0085981

Aderibigbe, B. A. (2017). Metal-based nanoparticles for the treatment of infectious diseases. Molecules 22:1370. doi: 10.3390/molecules22081370

Adetunji, C. O. (2019). Environmental Impact and Ecotoxicological Influence of Biofabricated and Inorganic Nanoparticle on Soil Activity, Nanotechnology for Agriculture. Singapore: Springer. doi: 10.1007/978-981-32-9370-0_12

Agarwal, A., Huang, S., O'donnell, M., Day, K., Day, M., Kotov, N., et al. (2007). Targeted gold nanorod contrast agent for prostate cancer detection by photoacoustic imaging. Int. J. Appl. Phys. 102, 64-70. doi: 10.1063/1.2777127

Agarwal, H., Nakara, A., and Shanmugam, V. K. (2019). Anti-inflammatory mechanism of various metal and metal oxide nanoparticles synthesized using plant extracts: a review. Biomed. Pharmacother. 109, 2561-2572. doi: 10.1016/j.biopha.2018.11.116

Ahmed, K. B. A., Subramanian, S., Sivasubramanian, A., Veerappan, G., and Veerappan, A. (2014). Preparation of gold nanoparticles using Salicornia brachiata plant extract and evaluation of catalytic and antibacterial activity. Spectrochimica Acta Part A 130, 54-58. doi: 10.1016/j.saa.2014. 03.070

Akram, F. E., El-Tayeb, T., Abou-Aisha, K., and El-Azizi, M. (2016). A combination of silver nanoparticles and visible blue light enhances the antibacterial efficacy of ineffective antibiotics against methicillin-resistant staphylococcus aureus (MRSA). Ann. Clin. Microb. Anti. 15:48. doi: 10.1186/s12941-0160164-y

Alam, M. M., Rashid, M. M. O., Hossen, F., Akhter, K. N., Nishat, S. A., and Wahab, A. (2017). Antibacterial activity of silver-extract nanoparticles synthesized from the combination of silver nanoparticles and M. charantia Fruit Extract. J. Drug Deliv. Sci. Technol. 7, 112-116. doi: 10.22270/jddt.v7i3.1458

Ambrosi, A., Airo, F., and Merkoçi, A. (2009). Enhanced gold nanoparticle based ELISA for a breast cancer biomarker. Anal. Chem. 82, 1151-1156. doi: $10.1021 /$ ac $902492 \mathrm{c}$

Azharuddin, M., Zhu, G. H., Das, D., Ozgur, E., Uzun, L., Turner, A. P., et al. (2019). A repertoire of biomedical applications of noble metal nanoparticles. Chem. Commun. 55, 6964-6996. doi: 10.1039/C9CC01741K

Aziz, Z. A. A., Mohd-Nasir, H., Ahmad, A., Mohd. Setapar, S. H., Peng, W. L., Chuo, S. C., et al. (2019). Role of nanotechnology for design and development of cosmeceutical: application in makeup and skin care. Front. Chem. 7:739. doi: 10.3389/fchem.2019.00739

Bagga, P., Ansari, T. M., Siddiqui, H. H., Syed, A., Bahkali, A. H., Rahman, M. A., et al. (2016). Bromelain capped gold nanoparticles as the novel drug delivery carriers to aggrandize effect of the antibiotic levofloxacin. EXCLI J. 15, 772-780. doi: 10.17179/excli2016-710

Bai, Y., Zhou, Y., Liu, H., Fang, L., Liang, J., and Xiao, S. (2018). glutathione-stabilized fluorescent gold nanoclusters vary in their influences on the proliferation of pseudorabies virus and porcine reproductive and respiratory syndrome virus. ACS Appl. Nano Mater. 1, 969-976. doi: $10.1021 /$ acsanm.7b00386

Bakuru, V. R., Velaga, B., Peela, N. R., and Kalidindi, S. B. (2018). Hybridization of Pd nanoparticles with UiO-66 (Hf) metal-organic framework and the effect of nanostructure on the catalytic properties. Chem. A Eur. J. 24, 15978-15982. doi: 10.1002/chem.201803200

Bankar, A., Joshi, B., Kumar, A. R., and Zinjarde, S. (2010). Banana peel extract mediated synthesis of gold nanoparticles. Coll. Surf. B 80, 45-50. doi: 10.1016/j.colsurfb.2010.05.029

\section{ACKNOWLEDGMENTS}

The authors gratefully acknowledge Universiti Sains Malaysia (USM), Penang Malaysia, 11800, for the financial assistance under the grant no. USM Bridging Grant 304.PKIMIA.6316507.

Baram-Pinto, D., Shukla, S., Gedanken, A., and Sarid, R. (2010). Inhibition of HSV1 attachment, entry, and cell-to-cell spread by functionalized multivalent gold nanoparticles. Small 6, 1044-1050. doi: 10.1002/smll.200902384

Baram-Pinto, D., Shukla, S., Perkas, N., Gedanken, A., and Sarid, R. (2009). Inhibition of herpes simplex virus type 1 infection by silver nanoparticles capped with mercaptoethane sulfonate. Bioconjugate Chem. 20, 1497-1502. doi: 10.1021/bc900215b

Barrabés, N., and Sá, J. (2011). Catalytic nitrate removal from water, past, present and future perspectives. App. Catal. B Environ. 104, 1-5. doi: 10.1016/j.apcatb.2011.03.011

Batchelor-McAuley, C., Tschulik, K., Neumann, C. C., Laborda, E., and Compton, R. G. (2014). Why are silver nanoparticles more toxic than bulk silver? Towards understanding the dissolution and toxicity of silver nanoparticles. Int. J. Electrochem. Sci. 9:1132.

Bharathiraja, S., Bui, N. Q., Manivasagan, P., Moorthy, M. S., Mondal, S., Seo, H., et al. (2018). Multimodal tumor-homing chitosan oligosaccharidecoated biocompatible palladium nanoparticles for photo-based imaging and therapy, Sci. Rep. 8:500. doi: 10.1038/s41598-017-18966-8

Bierkandt, F. S., Leibrock, L., Wagener, S., Laux, P., and Luch, A. (2018). The impact of nanomaterial characteristics on inhalation toxicity. Toxicol. Res 7 , 321-346. doi: 10.1039/C7TX00242D

Bindhu, M., and Umadevi, M. (2014). Antibacterial activities of green synthesized gold nanoparticles. Mater. Lett. 120, 122-125. doi: 10.1016/j.matlet.2014.01.108

Bowman, M-C., Ballard, T. E., Ackerson, C. J., Feldheim, D. L., Margolis, D. M., and Melander, C. (2008). Inhibition of HIV fusion with multivalent gold nanoparticles. Am. Chem. Soc. 130, 6896-6897. doi: 10.1021/ja710321g

Bracey, C. L., Ellis, P. R., and Hutchings, G. J. (2009). Application of copper-gold alloys in catalysis: current status and future perspectives. Chem. Soc. Rev. 38, 2231-2243. doi: 10.1039/b817729p

Brinãs, R. P., Sundgren, A., Sahoo, P., Morey, S., Rittenhouse-Olson, K., Wilding, G. E., et al. (2012). Design and synthesis of multifunctional gold nanoparticles bearing tumor-associated glycopeptide antigens as potential cancer vaccines Bioconjug. Chem. 23, 1513-1523. doi: 10.1021/bc200606s

Burygin, G., Khlebtsov, B., Shantrokha, A., Dykman, L., Bogatyrev, V., and Khlebtsov, N. (2009). On the enhanced antibacterial activity of antibiotics mixed with gold nanoparticles. Nanoscale Res. lett. 4:794. doi: 10.1007/s11671-009-9316-8

Cai, H., Degliangeli, F., Palitzsch, B., Gerlitzki, B., Kunz, H., Schmitt, E. et al. (2016). Glycopeptide-functionalized gold nanoparticles for antibody induction against the tumor associated Mucin-1 glycoprotein. Bioorg. Med. Chem. 24 1132-1135. doi: 10.1016/j.bmc.2016.01.044

Chaloupka, K., Malam, Y., and Seifalian, A. M. (2010). Nanosilver as a new generation of nanoproduct in biomedical applications. Trend Biotechnol. 28, 580-588. doi: 10.1016/j.tibtech.2010.07.006

Chesney, M. A. (2006). The elusive gold standard: future perspectives for HIV adherence assessment and intervention. J. Acquir. Immun. Defic. Syndr. 43, S149-S155. doi: 10.1097/01.qai.0000243112.91293.26

Chiodo, F., Marradi, M., Calvo, J., Yuste, E., and Penadés, S. (2014). Glycosystems in nanotechnology: gold glyconanoparticles as carrier for anti-HIV prodrugs. Beils. J. Org. Chem. 10, 1339-1346. doi: 10.3762/bjoc.10.136

Chitra, M. A. (2018). Rapid detection of staphylococcus aureus genomic dna using peptide nucleic acid and gold nanoparticles. Proc. Natl. Acad. Sci. U.S.A. 88, 803-811. doi: 10.1007/s40011-016-0820-1

Chon, H., Lee, S., Son, S. W., Oh, C. H., and Choo, J. (2009). Highly sensitive immunoassay of lung cancer marker carcinoembryonic antigen using surfaceenhanced Raman scattering of hollow gold nanospheres. Anal. Chem. 81, 3029-3034. doi: 10.1021/ac802722c 
Conde, J., Doria, G., and Baptista, P. (2012). Noble metal nanoparticles applications in cancer. J. Drug Deliv. 2012:751075. doi: 10.1155/2012/751075

Coradeghini, R., Gioria, S., García, C. P., Nativo, P., Franchini, F., Gilliland, D., et al. (2013). Size-dependent toxicity and cell interaction mechanisms of gold nanoparticles on mouse fibroblasts. Toxicol. Lett. 217, 205-216. doi: 10.1016/j.toxlet.2012.11.022

Cui, Y.-H., Hu, Z.-X., Gao, Z.-X., Song, X.-L., Feng, Q.-Y., Yang, G., et al. (2018). Airborne particulate matter impairs corneal epithelial cells migration via disturbing FAK/RhoA signaling pathway and cytoskeleton organization. Nanotox 12, 312-324. doi: 10.1080/17435390.2018.1440651

Daniel, M.-C., and Astruc, D. (2004). Gold nanoparticles: assembly, supramolecular chemistry, quantum-size-related properties, and applications toward biology, catalysis, and nanotechnology. Chem. Rev. 104, 293-346. doi: $10.1021 /$ cr030698+

Das, P., Fatehbasharzad, P., Colombo, M., Fiandra, L., and Prosperi, D. (2019). Multifunctional magnetic gold nanomaterials for cancer. Trends Biotechnol. 37, 995-1010. doi: 10.1016/j.tibtech.2019.02.005

Dasari, T. S., Zhang, Y., and Yu, H. (2015). Antibacterial activity and cytotoxicity of gold (I) and (III) ions and gold nanoparticles. Biochem. Pharmacol. 4:199. doi: 10.4172/2167-0501.1000199

Deng, H., McShan, D., Zhang, Y., Sinha, S. S., Arslan, Z., Ray, P. C., et al. (2016). Mechanistic study of the synergistic antibacterial activity of combined silver nanoparticles and common antibiotics. Environ. Sci. Technol. 50, 8840-8848. doi: 10.1021/acs.est.6b00998

Di-Gianvincenzo, P., Chiodo, F., Marradi, M., and Penadés, S. (2012). Gold manno-glyconanoparticles for intervening in HIV gp120 carbohydrate-mediated processes. Methods Enzymol. 509, 21-40. doi: 10.1016/B978-0-12-391858-1.00002-2

Dumas, A., and Couvreur, P. (2015). Palladium: a future key player in the nanomedical field? Chem. Sci. 6, 2153-2157. doi: 10.1039/C5SC00070J

Eck, W., Craig, G., Sigdel, A., Ritter, G., Old, L. J., Tang, L., et al. (2008). PEGylated gold nanoparticles conjugated to monoclonal F19 antibodies as targeted labeling agents for human pancreatic carcinoma tissue. ACS Nano 2, 2263-2272. doi: 10.1021/nn800429d

Elechiguerra, J. L., Burt, J. L., Morones, J. R., Camacho-Bragado, A., Gao, X., Lara, H. H., et al. (2005). Interaction of silver nanoparticles with HIV-1. J. Nanobiotechnol. 3:6. doi: 10.1186/1477-3155-3-6

El-Sayed, I. H., Huang, X., and El-Sayed, M. A. (2005). Surface plasmon resonance scattering and absorption of anti-EGFR antibody conjugated gold nanoparticles in cancer diagnostics: applications in oral cancer. Nano Lett. 5, 829-834. doi: $10.1021 / \mathrm{nl} 050074 \mathrm{e}$

Fard, J. K., Jafari, S., and Eghbal, M. A. (2015). A review of molecular mechanisms involved in toxicity of nanoparticles. Adv. Pharmaceut. Bull. 5, 447-454. doi: 10.15171/apb.2015.061

Filli, M. S., Ibrahim, A. A., Aquib, M., Abbas, A. B., Morshed, A., BoakyeYiadom, K. O., et al. (2019). The impact of physicochemical characteristics on therapeutic efficacy of anticancer nanomaterials: a review. Int. J. Pharmaceut. Sci. Drug Res. 11, 61-70. doi: 10.25004/IJPSDR.2019.110203

Gahlawat, G., and Choudhury, A. R. (2019). A review on the biosynthesis of metal and metal salt nanoparticles by microbes. RSC Adv. 9, 12944-12967. doi: 10.1039/C8RA10483B

Garrido, C., Simpson, C. A., Dahl, N. P., Bresee, J., Whitehead, D. C., Lindsey, E. A., et al. (2015). Gold nanoparticles to improve HIV drug delivery. Future Med. Chem. 7, 1097-1107. doi: 10.4155/fmc.15.57

Gliga, A. R., Skoglund, S., Wallinder, I. O., Fadeel, B., and Karlsson, H. L. (2014). Size-dependent cytotoxicity of silver nanoparticles in human lung cells: the role of cellular uptake, agglomeration and Ag release. Part Fibre Toxicol. 11:11. doi: 10.1186/1743-8977-11-11

Goodman, C. M., McCusker, C. D., Yilmaz, T., and Rotello, V. M. (2004). Toxicity of gold nanoparticles functionalized with cationic and anionic side chains. Bioconjugate Chem. 15, 897-900. doi: 10.1021/bc049951i

Gu, H., Ho, P., Tong, E., Wang, L., and Xu, B. (2003). Presenting vancomycin on nanoparticles to enhance antimicrobial activities. Nano Lett. 3, 1261-1263. doi: $10.1021 / \mathrm{nl} 034396 \mathrm{z}$

Gurunathan, S., Qasim, M., Park, C. H., Arsalan Iqbal, M., Yoo, H., Hwang, J. H., et al. (2019). Cytotoxicity and transcriptomic analyses of biogenic palladium nanoparticles in human ovarian cancer cells (SKOV3). Nanomater 9:787. doi: $10.3390 /$ nano 9050787
Handoko, C. T., Huda, A., and Gulo, F. (2019). Synthesis pathway and powerful antimicrobial properties of silver nanoparticle: a critical review. Asian J. Sci. Res. 12, 1-17. doi: 10.3923/ajsr.2019.1.17

He, F., Shen, Q., Jiang, H., Zhou, J., Cheng, J., Guo, D., et al. (2009). Rapid identification and high sensitive detection of cancer cells on the gold nanoparticle interface by combined contact angle and electrochemical measurements. Talanta 77, 1009-1014. doi: 10.1016/j.talanta.2008.07.063

Heo, D. N., Yang, D. H., Moon, H.-J., Lee, J. B., Bae, M. S., Lee, S. C., et al. (2012). Gold nanoparticles surface-functionalized with paclitaxel drug and biotin receptor as theranostic agents for cancer therapy. Biomaterials 33, 856-866. doi: 10.1016/j.biomaterials.2011.09.064

Her, S., Jaffray, D. A., and Allen, C. (2017). Gold nanoparticles for applications in cancer radiotherapy: mechanisms and recent advancements. Adv. Drug Deliv. Rev. 109, 84-101. doi: 10.1016/j.addr.2015.12.012

Ho, J. A. A., Chang, H.-C., Shih, N.-Y., Wu, L.-C., Chang, Y.-F., Chen, C.-C., et al. (2010). Diagnostic detection of human lung cancer-associated antigen using a gold nanoparticle-based electrochemical immunosensor. Anal. Chem. 82, 5944-5950. doi: 10.1021/ac1001959

Hong, X., Wen, J., Xiong, X., and Hu, Y. (2016). Shape effect on the antibacterial activity of silver nanoparticles synthesized via a microwave-assisted method. Environ. Sci. Pollut. Res. 23, 4489-4497. doi: 10.1007/s11356-015-5668-z

Hu, R., Li, S., Kong, F., Hou, R., Guan, X., and Guo, F. (2014). Inhibition effect of silver nanoparticles on herpes simplex virus 2. Genet. Mol. Res. 13, 7022-7028. doi: 10.4238/2014.March.19.2

Huang, S. H., and Juang, R. S. (2011). Biochemical and biomedical applications of multifunctional magnetic nanoparticles: a review. J Nanoparticle Res. 13:4411. doi: 10.1007/s11051-011-0551-4

Huang, W., Wang, C., Duan, H., Bi, Y., Wu, D., Du, J., et al. (2018). Synergistic antifungal effect of biosynthesized silver nanoparticles combined with fungicides. Int. J. Agric. Biol. 20, 1225-1229. doi: 10.17957/IJAB/15.0595

Huang, X., Tang, S., Mu, X., Dai, Y., Chen, G., Zhou, Z., et al. (2011a). Freestanding palladium nanosheets with plasmonic and catalytic properties. Nat. Nanotechnol. 6:28. doi: 10.1038/nnano.2010.235

Huang, X., Tang, S., Yang, J., Tan, Y., and Zheng, N. (2011b). Etching growth under surface confinement: an effective strategy to prepare mesocrystalline $\mathrm{Pd}$ nanocorolla. J. Am. Chem. Soc. 133, 15946-15949. doi: 10.1021/ja207788h

Jabr-Milane, L., van Vlerken, L., Devalapally, H., Shenoy, D., Komareddy, S., Bhavsar, M., et al. (2008). Multi-functional nanocarriers for targeted delivery of drugs and genes. J. Control. Rel. 130, 121-128. doi: $10.1016 /$ j.jconrel.2008.04.016

Kah, J. C. Y., Kho, K. W., Lee, C. G. L., and Richard, C. J. (2007). Early diagnosis of oral cancer based on the surface plasmon resonance of gold nanoparticles. Int. J. Nanomed. 2:785.

Kesarkar, R., Oza, G., Pandey, S., Dahake, R., Mukherjee, S., Chowdhary, A., et al. (2012). Gold nanoparticles: effective as both entry inhibitors and virus neutralizing agents against HIV. J. Microbiol. Biotech. Res. 2, 276-283.

Khadpekar, A. J., Khan, M., Sose, A., and Majumder, A. (2019). Low Cost and Lithography-free stamp fabrication for Microcontact printing. Sci. Report. 9:1024. doi: 10.1038/s41598-018-36521-x

Khatami, M., Sharifi, I., Nobre, M. A., Zafarnia, N., and Aflatoonian, M. R. (2018). Waste-grass-mediated green synthesis of silver nanoparticles and evaluation of their anticancer, antifungal and antibacterial activity. Green. Chem. Lett. Rev. 11, 125-134. doi: 10.1080/17518253.2018.1444797

Khlebtsov, N., and Dykman, L. (2011). Biodistribution and toxicity of engineered gold nanoparticles: a review of in vitro and in vivo studies. Chem. Soc. Rev. 40, 1647-1671. doi: 10.1039/C0CS00018C

Kim, J. D. (2019). "Nanomedicine: dynamic integration of nanotechnology with biomedical," in Nanomedicine: A Systems Engineering Approach, eds R. Bawa, G. F. Audette, and I. Rubinstein (Oxfordshire: Taylor \& francis group).

Kumar, A., Boruah, B. M., and Liang, X.-J. (2011). Gold nanoparticles: promising nanomaterials for the diagnosis of cancer and HIV/AIDS. J. Nanomater. 17, 1687-4110. doi: 10.1155/2011/202187

Lara, H. H., Ayala-Nuñez, N. V., Ixtepan-Turrent, L., and Rodriguez-Padilla, C. (2010). Mode of antiviral action of silver nanoparticles against HIV-1. J. Nanobiotechnol. 8:1. doi: 10.1186/1477-3155-8-1

Lara, H. H., Garza-Treviño, E. N., Ixtepan-Turrent, L., and Singh, D. K. (2011). Silver nanoparticles are broad-spectrum bactericidal and virucidal compounds. J. Nanobiotechnol. 9:30. doi: 10.1186/1477-3155-9-30 
Lazarević, T., Rilak, A., and Bugarčić, Ž.D. (2017). Platinum, palladium, gold and ruthenium complexes as anticancer agents: Current clinical uses, cytotoxicity studies and future perspectives. Eur. J. med chem. 142, 8-31. doi: 10.1016/j.ejmech.2017.04.007

Leso, V., Fontana, L., Marinaccio, A., Leopold, K., Fanali, C., Lucchetti, D., et al. (2019). Sub-chronic palladium nanoparticle effects on the endocrine reproductive system of female Wistar rats: preliminary data. Toxicol. Industr. Health 35, 403-409. doi: 10.1177/0748233719851702

Leso, V., and Iavicoli, I. (2018). Palladium nanoparticles: toxicological effects and potential implications for occupational risk assessment. Int. J. Mol. Sci. 19:503. doi: 10.3390/ijms19020503

Li, P., Li, J., Wu, C., Wu, Q., and Li, J. (2005). Synergistic antibacterial effects of $\beta$ lactam antibiotic combined with silver nanoparticles. Nanotechnology 16:1912. doi: 10.1088/0957-4484/16/9/082

Li, X., Robinson, S. M., Gupta, A., Saha, K., Jiang, Z., Moyano, D. F., et al. (2014). Functional gold nanoparticles as potent antimicrobial agents against multidrug-resistant bacteria. ACS Nano 8, 10682-10686. doi: 10.1021/nn5042625

Likus, W., Bajor, G., and Siemianowicz, K. (2013). Nanosilver-does it have only one face? Acta Biochim. Polonica 60, 495-505. doi: 10.18388/abp.2013_2013

Lima, E., Guerra, R., Lara, V., and Guzmán, A. (2013). Gold nanoparticles as efficient antimicrobial agents for Escherichia coli and Salmonella typhi. Chem. Central J. 7:11. doi: 10.1186/1752-153X-7-11

Ma, W., He, S., Ma, H., Jiang, H., Yan, N., Zhu, L., et al. (2020). Silver nanoparticle exposure causes pulmonary structural damage and mitochondrial dynamic imbalance in the rat: protective effects of sodium selenite. Int. J. Nanomed. 15, 633-645. doi: 10.2147/IJN.S232986

Marambio-Jones, C., and Hoek, E. M. (2010). A review of the antibacterial effects of silver nanomaterials and potential implications for human health and the environment. J. Nano. Res. 12, 1531-1551. doi: 10.1007/s11051-010-9900-y

Marradi, M., Di Gianvincenzo, P., Enriquez-Navas, P. M., Martinez-A' vila, O. M., Chiodo, F., Yuste, E., et al. (2011). Gold nanoparticles coated with oligomannosides of HIV-1 glycoprotein gp120 mimic the carbohydrate epitope of antibody 2G12. J. Mol. Biol. 410, 798-810. doi: 10.1016/j.jmb.2011. 03.042

Martinez-A' vila, O., Hijazi, K., Marradi, M., Clavel, C., Champion, C., Kelly, C., et al. (2009). Gold manno-glyconanoparticles: multivalent system to block HIV-1 gp120 binding to the lectin DC-SIGN. Chem. Eur. J. 15, 8974-9888. doi: 10.1002/chem.200900923

Medley, C. D., Smith, J. E., Tang, Z., Wu, Y., Bamrungsap, S., and Tan, W. (2008). Gold nanoparticle-based colorimetric assay for the direct detection of cancerous cells. Anal. Chem. 80, 1067-1072. doi: 10.1021/ac702037y

Mendoza-Pérez, R., and Guisbiers, G. (2019). Bimetallic Pt-Pd nanocatalyst: size, shape and composition matter. Nanotechnology 30:305702. doi: 10.1088/1361-6528/ab1759

Mohamed, M. M., Fouad, S. A., Elshoky, H. A., Mohammed, G. M., and Salaheldin, T. A. (2017). Antibacterial effect of gold nanoparticles against Corynebacterium pseudotuberculosis. Int. J. Vet. Med. Sci. 5, 23-29. doi: 10.1016/j.ijvsm.2017.02.003

Montalvo-Quiros, S., and Luque-Garcia, J. L. (2019). Combination of bioanalytical approaches and quantitative proteomics for the elucidation of the toxicity mechanisms associated to $\mathrm{TiO} 2$ nanoparticles exposure in human keratinocytes. Food. Chem. Toxicol. 127, 197-205. doi: 10.1016/j.fct.2019.03.036

MubarakAli, D., Thajuddin, N., Jeganathan, K., and Gunasekaran, M. (2011). Plant extract mediated synthesis of silver and gold nanoparticles and its antibacterial activity against clinically isolated pathogens. Colloid Surface B 85, 360-365. doi: 10.1016/j.colsurfb.2011.03.009

Murphy, M., Ting, K., Zhang, X., Soo, C., and Zheng, Z. (2015). Current development of silver nanoparticle preparation, investigation, and application in the field of medicine. J. Nanomater. 2015:696918. doi: 10.1155/2015/696918

Murugan, K., Panneerselvam, C., Samidoss, C. M., Madhiyazhagan, P., Suresh, U., Roni, M., et al. (2016). In vivo and in vitro effectiveness of azadirachta indicasynthesized silver nanocrystals against Plasmodium berghei and Plasmodium falciparum, and their potential against malaria mosquitoes. Res. Vet. Sci. 106, 14-22. doi: 10.1016/j.rvsc.2016.03.001

Nadhman, A., Khan, M. I., Nazir, S., Khan, M., Shahnaz, G., Raza, A., et al. (2016). Annihilation of leishmania by daylight responsive $\mathrm{ZnO}$ nanoparticles: a temporal relationship of reactive oxygen species-induced lipid and protein oxidation. Int. J. Nanomed. 11, 24-51. doi: 10.2147/IJN.S105195
Ngwa, W., Kumar, R., Sridhar, S., Korideck, H., Zygmanski, P., Cormack, R. A., et al. (2014). Targeted radiotherapy with gold nanoparticles: current status and future perspectives. Nanomedicine 9, 1063-1082. doi: 10.2217/nnm.14.55

Ojeda, R., de Paz, J. L., Barrientos, A. G., Martin-Lomas, M., and Penades, S. (2007). Preparation of multifunctional glyconanoparticles as a platform for potential carbohydrate-based anticancer vaccines. Carbohydr. Res. 342, 448-459.doi: 10.1016/j.carres.2006.11.018

Pal, S., Tak, Y. K., and Song, J. M. (2007). Does the antibacterial activity of silver nanoparticles depend on the shape of the nanoparticle? A study of the gramnegative bacterium Escherichia coli. Appl. Environ. Microbiol. 73, 1712-1720. doi: 10.1128/AEM.02218-06

Parry, A. L., Clemson, N. A., Ellis, J., Bernhard, S. S. R., Davis, B. G., Neil, R., et al. (2013). Multicopy multivalent' glycopolymer-stabilized gold nanoparticles as potential synthetic cancer vaccines. J. Am. Chem. Soc. 135, 9362-9365. doi: $10.1021 /$ ja 4046857

Pattadar, D. K., Sharma, J. N., Mainali, B. P., and Zamborini, F. P. (2019). Anodic stripping electrochemical analysis of metal nanoparticles. Curr. Opin. Electrochem. 13, 147-156. doi: 10.1016/j.coelec.2018.12.006

Pillai, G. (2019). Nanotechnology Toward Treating Cancer: A Comprehensive Review, Applications of Targeted Nano Drugs and Delivery Systems. Oxford: Elsevier. doi: 10.1016/B978-0-12-814029-1.00009-0

Potineni, A., Lynn, D. M., Langer, R., and Amiji, M. M. (2003). Poly (ethylene oxide)-modified poly ( $\beta$-amino ester) nanoparticles as a $\mathrm{pH}$-sensitive biodegradable system for paclitaxel delivery. J. Control. Rel. 86, 223-234. doi: $10.1016 /$ S0168-3659(02)00374-7

Prasad, T., and Elumalai, E. (2011). Biofabrication of Ag nanoparticles using Moringa oleifera leaf extract and their antimicrobial activity. Asian Pac. J. Trop. Biomed. 1, 439-442. doi: 10.1016/S2221-1691(11)60096-8

Rafiei, S., Rezatofighi, S. E., Ardakani, M. R., and Madadgar, O. (2018), Restrictive influence of silver nanoparticles on the life cycle of the foot-and-mouth disease virus. Nanosci. Nanotechnol. Asia 8, 248-254. doi: $10.2174 / 2210681207666170703155244$

Raghavendra, R., Arunachalam, K., Annamalai, S. K., and Aarrthy, M. (2014). Diagnostics and therapeutic application of gold nanoparticles. Int. J. Pharm. Pharm. Sci. 6, 74-87.

Rahman, M., Abd-El-Barr, M., Mack, V., Tkaczyk, T., Sokolov, K., RichardsKortum, R., et al. (2005). Optical imaging of cervical pre-cancers with structured illumination: an integrated approach. Gynecol. Oncol. 99, S112S115. doi: 10.1016/j.ygyno.2005.07.053

Rai, A., Comune, M., and Ferreira, L. (2019). Nanoparticle-Based Drug Delivery Systems: Promising Approaches Against Bacterial Infections, Antibacterial Drug Discovery to Combat MDR. Singapore: Springer. doi: 10.1007/978-981-13-9871-1_27

Rai, M., Ingle, A. P., Gaikwad, S., Padovani, F. H., and Alves, M. (2016). The role of nanotechnology in control of human diseases: perspectives in ocular surface diseases. Crit. Rev. Biotechnol. 36, 777-787. doi: 10.3109/07388551.2015.1036002

Rai, M., P., Ingle, A., R., Gupta, I., Birla, S., Yadav, A., and Abd-Elsalam, K. A. (2013). Potential role of biological systems in formation of nanoparticles: mechanism of synthesis and biomedical applications. Curr. Nanosci. 9, 576-587. doi: 10.2174/15734137113099990092

Rajathi, F. A. A., Parthiban, C., Kumar, V. G., and Anantharaman, P. (2012). Biosynthesis of antibacterial gold nanoparticles using brown alga, Stoechospermum marginatum (kützing). Spectrochimica Acta Part A 99, 166-173. doi: 10.1016/j.saa.2012.08.081

Rashid, M., and Ahmad, Q. Z. (2019). Trends in Nanotechnology for Practical Applications, Applications of Targeted Nano Drugs and Delivery Systems. Oxford: Elsevier. doi: 10.1016/B978-0-12-814029-1.00011-9

Rashid, M., and Sabir, S. (2014). Biosynthesis of self-dispersed silver colloidal particles using the aqueous extract of P. peruviana for Sensing dl-Alanine. ISRN Nanotechnol. 2:2014.

Rashid, M. M. O., Ferdous, J., Banik, S., Islam, M. R., Uddin, A. M., and Robel, F. N. (2016). Anthelmintic activity of silver-extract nanoparticles synthesized from the combination of silver nanoparticles and $M$. charantia fruit extract. $B M C$ 16:242. doi: 10.1186/s12906-016-1219-5

Rich, R. L., and Miszka, D. G. (2000). Advances in surface plasmon resonance biosensor analysis. Curr. Opin. Biotechnol. 11, 54-61. doi: 10.1016/S0958-1669(99)00054-3 
Rodriguez-Garraus, A., Azqueta, A., Vettorazzi, A., and López de Cerain, A. (2020). Genotoxicity of silver nanoparticles. Nanomaterials 10:251. doi: 10.3390/nano10020251

Romaniuk, J. A., and Cegelski, L. (2015). Bacterial cell wall composition and the influence of antibiotics by cell-wall and whole-cell NMR. ?Philos. Trans. Royal Soc. B. 370:20150024. doi: 10.1098/rstb.2015.0024

Sachse, A., Linares, N., Barbaro, P., Fajula, F., and Galarneau, A. (2013). Selective hydrogenation over Pd nanoparticles supported on a pore-flow-through silica monolith microreactor with hierarchical porosity. Dalton Trans. 42, 1378-1384. doi: 10.1039/C2DT31690K

Saha, B., Bhattacharya, J., Mukherjee, A., Ghosh, A., Santra, C., Dasgupta, A. K., et al. (2007). In vitro structural and functional evaluation of gold nanoparticles conjugated antibiotics. Nanoscale Res. Lett. 2:614-622. doi: 10.1007/s11671-007-9104-2

Sakthivel, C., Keerthana, L., and Prabha, I. (2019). Current status of platinum based nanoparticles: physicochemical properties and selected applications-a review. Johnson Matthey Tech. 63, 122-133. doi: 10.1595/205651319X15498900 266305

Santhoshkumar, T., Rahuman, A. A., Jayaseelan, C., Rajakumar, G., Marimuthu, S., Kirthi, A. V., et al. (2014). Green synthesis of titanium dioxide nanoparticles using Psidium guajava extract and its antibacterial and antioxidant properties. Asian Pac. J. Trop. Med. 7, 968-976. doi: 10.1016/S1995-7645(14)60171-1

Sarid, R., Gedanken, A., and Baram-Pinto, D. (2014). Pharmaceutical Compositions Comprising Water-Soluble Sulfonate-Protected Nanoparticles and Uses Thereof. Google Patents.

Shaikh, S., Nazam, N., Rizvi, S. M. D., Ahmad, K., Baig, M. H., Lee, E. J., et al. (2019). Mechanistic insights into the antimicrobial actions of metallic nanoparticles and their implications for multidrug resistance. Int. J. Mol. Sci. 20:2468. doi: 10.3390/ijms20102468

Shamaila, S., Zafar, N., Riaz, S., Sharif, R., Nazir, and, J., and Naseem, S. (2016). Gold nanoparticles: an efficient antimicrobial agent against enteric bacterial human pathogen. Nanomaterial 6:71. doi: 10.3390/nano6040071

Sharma, V. K., Sayes, C. M., Guo, B., Pillai, S., Parsons, J. G., Wang, C., et al. (2019). Interactions between silver nanoparticles and other metal nanoparticles under environmentally relevant conditions: a review. Sci. Total Environ. 653, 1042-1051. doi: 10.1016/j.scitotenv.2018.10.411

Shenoy, D., Little, S., Langer, R., and Amiji, M. (2005). Poly (ethylene oxide)modified poly ( $\beta$-amino ester) nanoparticles as a $\mathrm{pH}$-sensitive system for tumor-targeted delivery of hydrophobic drugs. 1. In vitro evaluations. Mol. Pharm. 2, 357-366. doi: 10.1021/mp0500420

Shi, X., Wang, S., Meshinchi, S., Van Antwerp, M. E., Bi, X., Lee, I., et al. (2007). Dendrimer-entrapped gold nanoparticles as a platform for cancercell targeting and imaging. Small 3, 1245-1252. doi: 10.1002/smll.2007 00054

Shirley, A. D., Dayanand, A., Sreedhar, B., and Dastager, S. (2010). Antimicrobial activity of silver nanoparticles synthesized from novel streptomyces species. Dig. J. Nanomater. Bios. 5, 447-451.

Shrivastava, S., Jain, S., Kumar, D., Soni, S. L., and Sharma, M. (2019). A review on theranostics: an approach to targeted diagnosis and therapy. Asian J. Pharm. Res. Dev. 7, 63-69. doi: 10.22270/ajprd.v7i2.463

Shubha, P., Gowda, M. L., Namratha, K., Manjunatha, H., and Byrappa, K. (2019). In vitro and in vivo evaluation of green-hydrothermal synthesized ZnO nanoparticles. J. Drug Deliv. Sci. Technol. 49, 692-699. doi: 10.1016/j.jddst.2018.12.017

Singh, P., Pandit, S., Mokkapati, V., Garg, A., Ravikumar, V., and Mijakovic, I. (2018). Gold nanoparticles in diagnostics and therapeutics for human cancer. Int. J. Mol. Sci. 19:1979. doi: 10.3390/ijms19071979

Singh, P. K., Kumar, P., and Das, A. K. (2019). Unconventional physical methods for synthesis of metal and non-metal nanoparticles: a review. Proc. Natl. Acad. Sci. U.S.A. 89, 199-221. doi: 10.1007/s40010-017-0474-2

Smekalova, M., Aragon, V., Panacek, A., Prucek, R., Zboril, R., and Kvitek, L. (2016). Enhanced antibacterial effect of antibiotics in combination with silver nanoparticles against animal pathogens. Vet. J. 209, 174-179. doi: 10.1016/j.tvjl.2015.10.032

Srinivasan, A., Karchmer, T., Richards, A., Song, X., and Perl, T. M. (2006). A prospective trial of a novel, silicone-based, silver-coated foley catheter for the prevention of nosocomial urinary tract infections. Infect. Cont. Hosp. Ep. 27, 38-43. doi: $10.1086 / 499998$
Stone, V., Miller, M., Clift, M., Elder, A., Mills, N., Møller, P., et al. (2016). Nanomaterials versus ambient ultrafine particles. an opportunity to exchange toxicology knowledge. Environ. Health Perspect. 125:106002. doi: 10.1289/EHP424

Sun, I. C., Eun, D. K., Na, J. H., Lee, S., Kim, I. J., Youn, I. C., et al. (2009). Heparincoated gold nanoparticles for liver-specific CT imaging. Chem. A Eur. J. 15, 13341-13347. doi: 10.1002/chem.200902344

Sun, R. W.-Y., Chen, R., Chung, N. P.-Y., Ho, C.-M., Lin, C.-L. S., and Che, C.-M. (2005). Silver nanoparticles fabricated in Hepes buffer exhibit cytoprotective activities toward HIV-1 infected cells. Chem Commun. 40, 5059-5061. doi: 10.1039/b510984a

Taubenberger, J. K., and Morens, D. M. (2008). The pathology of influenza virus infections. Annu. Rev. Pathmechdis. Mech. Dis. 3, 499-522. doi: 10.1146/annurev.pathmechdis.3.121806.154316

Taylor, U., Barchanski, A., Garrels, W., Klein, S., Kues, W., Barcikowski, S., et al. (2012). Toxicity of Gold Nanoparticles on Somatic and Reproductive Cells, NanoBiotechnology for Biomedical and Diagnostic Research. Singapore: Springer. doi: 10.1007/978-94-007-2555-3 12

Tyagi, N., and Kumar, A. (2019). Understanding effect of interaction of nanoparticles and antibiotics on bacteria survival under aquatic conditions: Knowns and unknowns. Environ. Res. 181:108945. doi: 10.1016/j.envres.2019.108945

Valavanidis, A. (2019). Oxidative Stress and Pulmonary Carcinogenesis Through Mechanisms of Reactive Oxygen Species. How Respirable Particulate Matter, Fibrous Dusts, and Ozone Cause Pulmonary Inflammation and Initiate Lung Carcinogenesis. Singapore: Springer. doi: 10.1007/978-981-13-8413-4_13

Van der Zande, M., Vandebriel, R. J., Van Doren, E., Kramer, E., Herrera Rivera, Z., Serrano-Rojero, C. S., et al. (2012). Distribution, elimination, and toxicity of silver nanoparticles and silver ions in rats after 28-day oral exposure. ACS Nano 6, 7427-7442. doi: 10.1021/nn302649p

Verma, P., and Maheshwari, S. K. (2019). Applications of Silver nanoparticles in diverse sectors. Int. J. Nano. Dimension. 10, 18-36. doi: 10.22034/ijnd.2018.87646.1609

Wan, G., Ruan, L., Yin, Y., Yang, T., Ge, M., and Cheng, X. (2016). Effects of silver nanoparticles in combination with antibiotics on the resistant bacteria acinetobacter baumannii. Int. J. Nanomed. 11:3789. doi: 10.2147/IJN.S104166

Wang, X., Qian, X., Beitler, J. J., Chen, Z. G., Khuri, F. R., Lewis, M. M., et al. (2011). Detection of circulating tumor cells in human peripheral blood using surface-enhanced Raman scattering nanoparticles. Cancer Res. 71, 1526-1532. doi: 10.1158/0008-5472.CAN-10-3069

Wang, Y., Newell, B. B., and Irudayaraj, J. (2012). Folic acid protected silver nanocarriers for targeted drug delivery. J. Biomed. Nanotechnol. 8, 751-759. doi: 10.1166/jbn.2012.1437

Wei, J., Chen, X., Shi, S., Mo, S., and Zheng, N. (2015). An investigation of the mimetic enzyme activity of two-dimensional Pd-based nanostructures. Nanoscale 7, 19018-19026. doi: 10.1039/C5NR05675F

Xiao, J.-W., Fan, S.-X., Wang, F., Sun, L.-D., Zheng, X.-Y., and Yan, C.H. (2014). Porous Pd nanoparticles with high photothermal conversion efficiency for efficient ablation of cancer cells. Nanoscale 6, 4345-4351. doi: $10.1039 / C 3 N R 06843 \mathrm{~A}$

Yang, L., Kuang, H., Zhang, W., Aguilar, Z. P., Wei, H., and Xu, H. (2017). Comparisons of the biodistribution and toxicological examinations after repeated intravenous administration of silver and gold nanoparticles in mice. Sci. Rep. 7, 1-12. doi: 10.1038/s41598-017-03015-1

Yang, X., Gondikas, A. P., Marinakos, S. M., Auffan, M., Liu, J., Hsu-Kim, H., et al. (2011). Mechanism of silver nanoparticle toxicity is dependent on dissolved silver and surface coating in Caenorhabditis elegans. Environ. Sci. Technol. 46, 1119-1127. doi: 10.1021/es202417t

Yaqoob, A. A., Ahmad, H., Parveen, T., Ahmad, A., Oves, M., Ismail, I. M., et al. (2020c). Recent advances in metal decorated nanomaterials and their various biological applications: a review. Front. Chem. 8: 341. doi: $10.3389 /$ fchem.2020.00341

Yaqoob, A. A., Khan, R. M. R., and Saddique, A. (2019). Review article on applications and classification of gold nanoparticles. Int. J. Res. 6, 762-768. doi: 10.1088/1757-899X/263/3/032019

Yaqoob, A. A., Parveen, T., Umar, K., Ibrahim, M., and Nasir, M. (2020a). Role of nanomaterials in the treatment of wastewater: a review. Water 12:495. doi: 10.3390/w12020495 
Yaqoob, A. A., Umar, K., and Ibrahim, M. N. M. (2020b). Silver nanoparticles: various methods of synthesis, size affecting factors and their potential applications-a review. Appl. Nanosci. 10, 1369-1378. doi: 10.1007/s13204-020-01318-w

Zahir, A. A., Chauhan, I. S., Bagavan, A., Kamaraj, C., Elango, G., Shankar, J., et al. (2015). Green synthesis of silver and titanium dioxide nanoparticles using Euphorbia prostrata extract shows shift from apoptosis to G0/G1 arrest followed by necrotic cell death in Leishmania donovani. Antimicrob. Agents Chemother. 59, 4782-4799. doi: 10.1128/AAC.00098-15

Zhang, D., Liu, T., Cheng, J., Liang, S., Chai, J., Yang, X., et al. (2019). Controllable synthesis and characterization of tungsten disulfide nanosheets as promising nanomaterials for electronic devices. Ceramics Int. 45, 12443-12448. doi: 10.1016/j.ceramint.2019.03.177

Zhang, Y., Ferguson, S. A., Watanabe, F., Jones, Y., Xu, Y., Biris, A. S., et al. (2013). Silver nanoparticles decrease body weight and locomotor activity in adult male rats. Small 9, 1715-1720. doi: 10.1002/smll.201201548

Zhang, Y., Shareena Dasari, T. P., Deng, H., and Yu, H. (2015). Antimicrobial activity of gold nanoparticles and ionic gold. J. Environ. Sci. Health Part C 33, 286-327. doi: 10.1080/10590501.2015.1055161

Zharov, V. P., Mercer, K. E., Galitovskaya, E. N., and Smeltzer, M. S. (2006). Photothermal nanotherapeutics and nanodiagnostics for selective killing of bacteria targeted with gold nanoparticles. Biophys. J. 90, 619-627. doi: 10.1529/biophysj.105.061895

Zhou, F., Yuan, L., Wang, H., Li, D., and Chen, H. (2011). Gold nanoparticle layer: a promising platform for ultra-sensitive cancer detection. Langmuir 27, 2155-2158. doi: 10.1021/la1049937

Zhou, Y., Kong, Y., Kundu, S., Cirillo, J. D., and Liang, H. (2012). Antibacterial activities of gold and silver nanoparticles against Escherichia coli and bacillus Calmette-Guérin. J. Nanobiotechnol. 10:19. doi: 10.1186/1477-3155$10-19$

Conflict of Interest: The authors declare that the research was conducted in the absence of any commercial or financial relationships that could be construed as a potential conflict of interest.

Copyright (c) 2020 Yaqoob, Adnan, Rameez Khan and Rashid. This is an open-access article distributed under the terms of the Creative Commons Attribution License (CC $B Y)$. The use, distribution or reproduction in other forums is permitted, provided the original author(s) and the copyright owner(s) are credited and that the original publication in this journal is cited, in accordance with accepted academic practice. No use, distribution or reproduction is permitted which does not comply with these terms. 